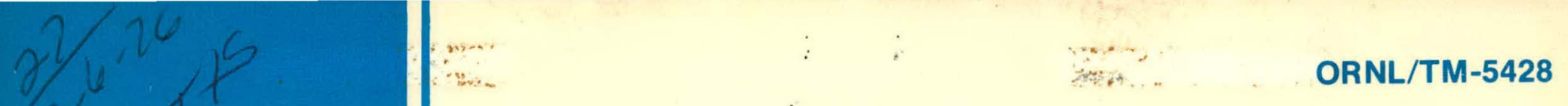

\title{
Process Energy Reliability Requirements for Selected Industries
}

William G. Sullivan

Thomas M. West 


\section{DISCLAIMER}

This report was prepared as an account of work sponsored by an agency of the United States Government. Neither the United States Government nor any agency Thereof, nor any of their employees, makes any warranty, express or implied, or assumes any legal liability or responsibility for the accuracy, completeness, or usefulness of any information, apparatus, product, or process disclosed, or represents that its use would not infringe privately owned rights. Reference herein to any specific commercial product, process, or service by trade name, trademark, manufacturer, or otherwise does not necessarily constitute or imply its endorsement, recommendation, or favoring by the United States Government or any agency thereof. The views and opinions of authors expressed herein do not necessarily state or reflect those of the United States Government or any agency thereof. 


\section{DISCLAIMER}

Portions of this document may be illegible in electronic image products. Images are produced from the best available original document. 


\section{Printed in the United States of America. Available from National Technical Information Service \\ U.S. Department of Commerce \\ 5285 Port Royal Road, Springfield, Virginia 22161}

Price: Printed Copy $\$ 4.50$; Microfiche $\$ 2.25$

This report was prepared as an account of work sponsored by the United States Government. Neither the United States nor the Energy Research and Development Administration/United States Nuclear Regulatory Commission, nor any of their employees, nor any of their contractors, subcontractors, or their employees, makes any warranty, express or implied, or assumes any legal liability or responsibility for the accuracy, completeness or usefulness of any information, apparatus, product or process disclosed, or represents that its use would not infringe privately owned rights. 


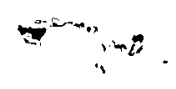

Contract No. W-7405-eng-26

Engineering Technology Division

PROCESS ENERGY RELIABILITY REQUIREMENTS FOR SELECTED INDUSTRIES

William G. Sullivan

Thomas M. West

Date Published: September 1976

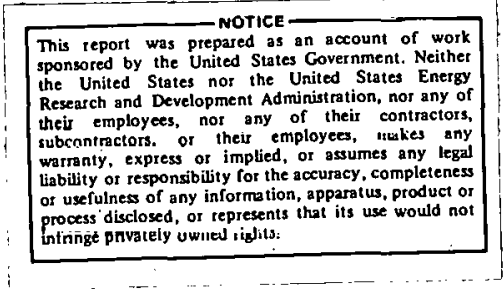


i

THIS PAGE

WAS INTENTIONALLY

LEFT BLANK 
CONTENTS

Page

ACKNOWLEDGMENTS . . . . . . . . . . . . . . . . . iv

ABSTRACT . . . . . . . . . . . . . . . . . . . . 1

INTRODUCTION . . . . . . . . . . . . . . . . . . . 1

SOURCES AND COSTS OF INDUSTRIAL PROCESS ENERGY . . . . . . 4

STUDY RESULTS FOR THE CHEMICAL INDUSTRY . . . . . . . . . . 8

STUDY RESULTS FOR PETROLEUM REFINERIES . . . . . . . . . . 23

STUDY RESULTS FOR PRIMARY METALS INDUSTRIES . . . . . . . . 32

CONCLUSIONS OF THE STUDY . . . . . . . . . . . . 39

REFERENCES .................... . . 41

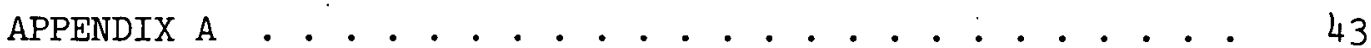


The authors wish to thank Otto $\mathrm{H}$. Klepper of the Engineering Technology Division for his thoughtful suggestions regarding the preparation of this report. We would also like to acknowledge the industrial contributors that provided our data and checked the manuscript for its accuracy. 


\title{
PROCESS ENERGY RELIABILITY REQUIREMENTS \\ FOR SELECTED INDUSTRIES
}

William G. Sullivan*

Thomas M. West**

\begin{abstract}
The purpose of this study was to obtain estimates of process energy reliability experience for selected plants in these industries: chemicals and allied products, petroleum refining and primary metals. Twenty-nine responses to the mail-out questionnaire were returned, and data for 1973-74 were analyzed with respect to steam generator characteristics, types of fuels used, amounts of electrical energy purchased or sold, and reliabilities of the steam-supply system. Reliability referred to the percentage of clock time that sufficient amounts of steam energy were available to permit desired production quotas to be met at a particular plant. For the 17 chemical industries, study results showed that reliabilities ranged from 100 to $89 \%$, and the average value was $98 \%$. The nine petroleum refineries experienced an average steam-supply system reliability of $92 \%$, with individual refinery reliabilities ranging from 100 to $70 \%$. Finally, there were only three primary metals companies represented in the study, and their process energy reliabilities were $100 \%$.
\end{abstract}

\section{INTRODUCTION}

Industry consumes a large share of the total primary energy used in the United States. Natural gas and oil, the major industrial fuels, are becoming scarce and expensive. Therefore, there is a critical national need to develop alternative sources of industrial energy based on the more plentiful domestic fuels - coal and nuclear. An important aspect of any alternative industrial energy system is the reliability required during long-term operation, such that the expected service continuity would meet industrial needs.

The aim of this study was to quantify the reliability requirements of process energy systems in selected energy-intensive industries. This was accomplished by developing a questionnaire (see Appendix A) and sending

\footnotetext{
*University of Tennessee, Knoxville, Tennessee, **Presently located at Oregon State University, Corvallis, Oregon.
} 
it to 65 companies in the following major industries: chemicals and allied products (S.I.C.28), petroleum refining and related industries (S.I.C.29), and primary metals industries (S.I.C.33). A detailed analysis of 29 responses to the questionnaire was performed and is reported in subsequent sections.

The combined energy consumption of these three industries accounts for approximately $50 \%$ of total industrial energy usage. ${ }^{1}$ Because roughly $40 \%$ of all energy in the United States is consumed each year by industrial processes, the chemical, petroleum refining, and primary metals industries represent $20 \%$ of this nation's total energy requirements. 2

Analysis of questionnaire responses was focused on quantifying the reliability of process steam systems in these three industries since classification of primary end-uses of fuels in industry indicates that a major fraction of industrial fuel is used to raise process steam. From Table $I$ it can be seen that $67 \%$ of all fuels consumed by the chemical industry are used to generate steam, while for the petroleum and primary metals industries the percentages are 36 and 21 respectively. Petroleum products represent over one half of industrial fuels; thus, substitution of alternative energy sources could save appreciable quantities of rapidly diminishing supplies of oil and natural gas.

For purposes of this study, reliability is dcfined to be the fraction of scheduled production time at a company that the production facility is in an "up" condition. This condition exists when the available capacity of the steam supply system equals or exceeds process energy requirements at the planned production level (i.e., "desired production level") that has been established independent of energy availability.

Reliability, as defined above, is a term that reflects the "consumer's" viewpoint in a corporate energy supply-demand relationship. From the "producer's" viewpoint (i.e., the power and steam generation group), the term availability is used to represent the percent of clock time in a continuous operation that individual boilers and/or reactors produce steam. Thus when reliability requirements of a company can be met or exceeded by the overall availability of its energy system, scheduled production levels are unaffected, and the facility is in an "up" condition. 
Table 1. Fuel distribution to combustion process (1971 data)

\begin{tabular}{|c|c|c|c|c|c|}
\hline \multirow[b]{2}{*}{ Industry/fiel } & \multicolumn{2}{|c|}{ Steam generation } & \multirow[b]{2}{*}{$\begin{array}{l}\text { Process heater } \\
\text { or furnace } \\
(\%)\end{array}$} & \multirow[b]{2}{*}{$\begin{array}{c}\text { Other } \\
(\%)\end{array}$} & \multirow[b]{2}{*}{$\begin{array}{c}\text { Total energy } \\
\text { kJ } \times 10^{12} / \text { year } \\
\text { (Btu } \times 10^{12} / \text { year) }\end{array}$} \\
\hline & $\begin{array}{c}\text { Under } 1379 \mathrm{kPa} \\
(200 \text { psia) } \\
(\%)\end{array}$ & $\begin{array}{c}\text { Over } 1379 \mathrm{kPa} \\
(200 \text { psia }) \\
(\%)\end{array}$ & & & \\
\hline \multicolumn{6}{|l|}{ Chemicals: } \\
\hline All fuels & 7 & 60 & 15 & 18 & $\begin{array}{l}2279 \\
(2160)\end{array}$ \\
\hline Oil and gas only & 8 & 64 & 7 & 21 & $\begin{array}{l}1720 \\
(1630)\end{array}$ \\
\hline \multicolumn{6}{|l|}{$\stackrel{a}{\text { Peíroleum: }}$} \\
\hline All fuels & 1 & 35 & 57 & 7 & $\begin{array}{l}2870 \\
(2720)\end{array}$ \\
\hline Oil and gas only & 1. & 38 & 53 & 8 & $\begin{array}{l}1488 \\
(1410)\end{array}$ \\
\hline \multicolumn{6}{|l|}{ Primary metals: } \\
\hline All fuels & - & 21 & 3 & 76 & $\begin{array}{c}3661 \\
(3470)\end{array}$ \\
\hline Oil and gas only & - & 35 & 6 & 59 & $\begin{array}{l}1403 \\
(1330)\end{array}$ \\
\hline
\end{tabular}

Source: Evaluation of New Energy Sources for Process Heat, Final Report of N.S.F. Grant No. OEP 74-18055, Prepared by the Dow Chemical Company (Midland, Michigan), September 1975, p. 39. 
It is believed that realistic industrial energy reliability requirements can be derived from industry operating experience that is acquired in the present survey. A follow-on study will then utilize these reliability estimates in determining feasible combinations of nuclear and/or nuclear-fossil systems capable of meeting current reliability levels in the three industries being considered.

SOURCES AND COSTS OF INDUSTRIAL PROCESS ENERGY

In the past, high steam supply availability has been relatively easy to obtain through the installation of multiple gas- and/or oil-fired boilers. Such installations were relatively inexpensive because the cost of providing high availability through excess capacity was considerably less than the cost of curtailed production resulting from insufficient steam. However, with increasing economies of scale, larger boiler installations and uncertainties concerning the availability of gas and oil, costs of providing high availability steam through the use of multiple (and redundant) boilers is becoming a point of concern.

Some idea of the economic attractiveness of nuclear-fieled steam generators can be obtained when their steam costs are compared with those of conventional fossil processes. A generalized comparison of costs shows that current coal-fired systems provide steam in the neighborhood of $\$ 1.61$ to $\$ 1.94$ per million kilojoules ( $\$ 1.53$ to $\$ 1.84$ per million Btu). ${ }^{3}$ Steam production with residual oil as fuel (at a conservative $\$ 57 / \mathrm{m}^{3}$, or $\$ 9 / \mathrm{bbl}$ ) costs approximately $\$ 2.37$ per million kilojoules ( $\$ 2.25$ per million Btu) based on standard assumptions concerning industrial financing, plant life, taxes, etc. ${ }^{4}$ These costs of generating steam can be compared with those for various nuclear units shown in Table 2 . While these data are based on 1974 economic parameters, they still provide a valid basis for purposes of comparison. For each of these basic types of nuclear steam generators, representative operating characteristics are summarized in Table 3. ' In view of current projections concerning price escalations of fossil fuels, the economics of nuclear steam generators have tended to become more favorable relative to conventional systems. In this regard, estimates of future fuel costs are shown in Fig. 1 . 
Table 2. Estimated cost of process steam from different size nuclear units (1974 cost basis)

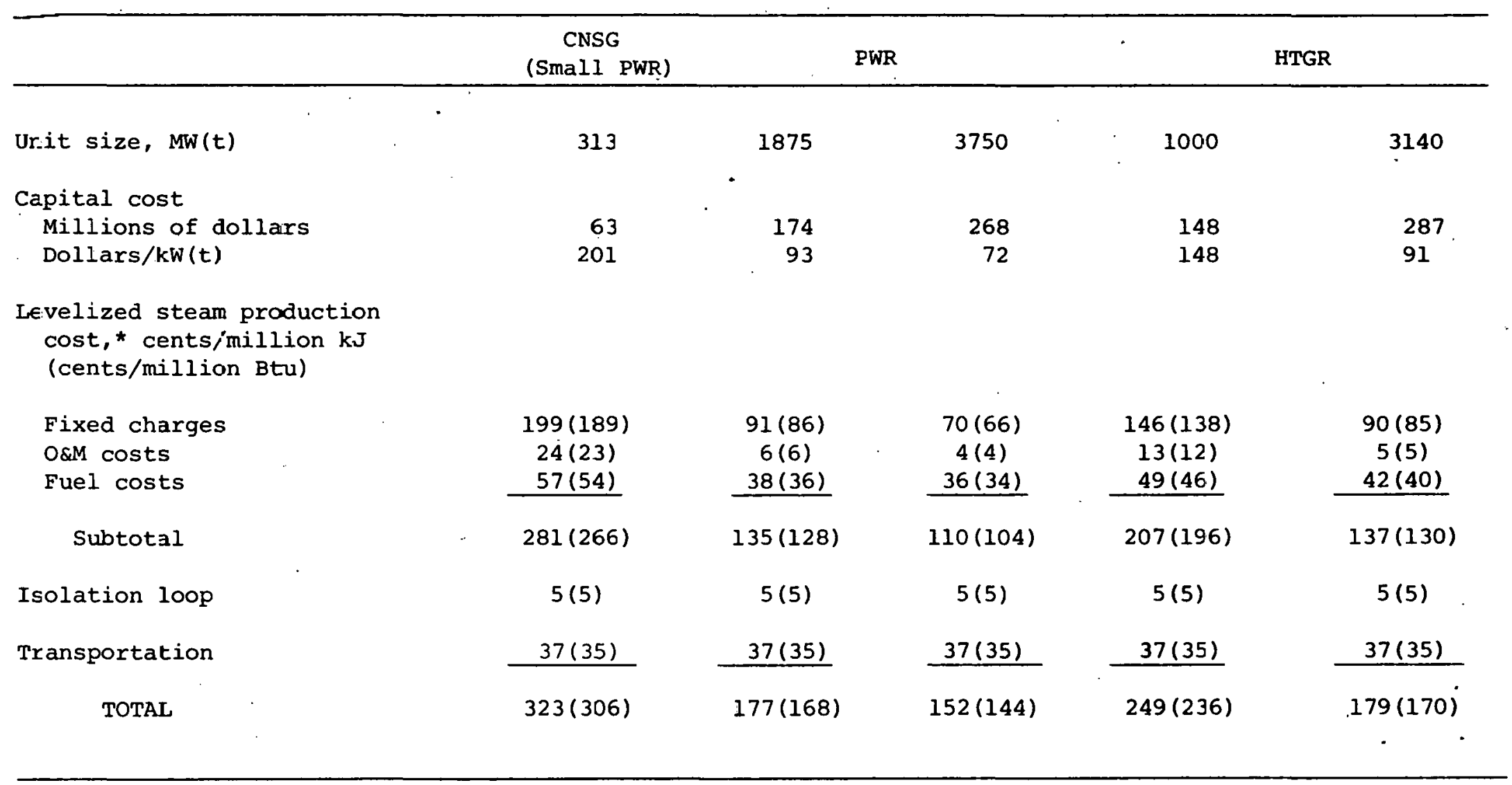

*Based on $80 \%$ plant factor and industrial ownership with a fixed charge rate of 22.28 .

Source: D. B. Trauger, L. L. Bennett, and H. I. Bowers, "Nuclear Reactor Process Heat Capabilities, Potential and Economics," Proceedings of the First National Topical Meeting on Nuclear Process Heat Applications, Los Alamos, New Mexico, October 1974, p. 27. 
Table 3. Representative operating characteristics of typical reactors

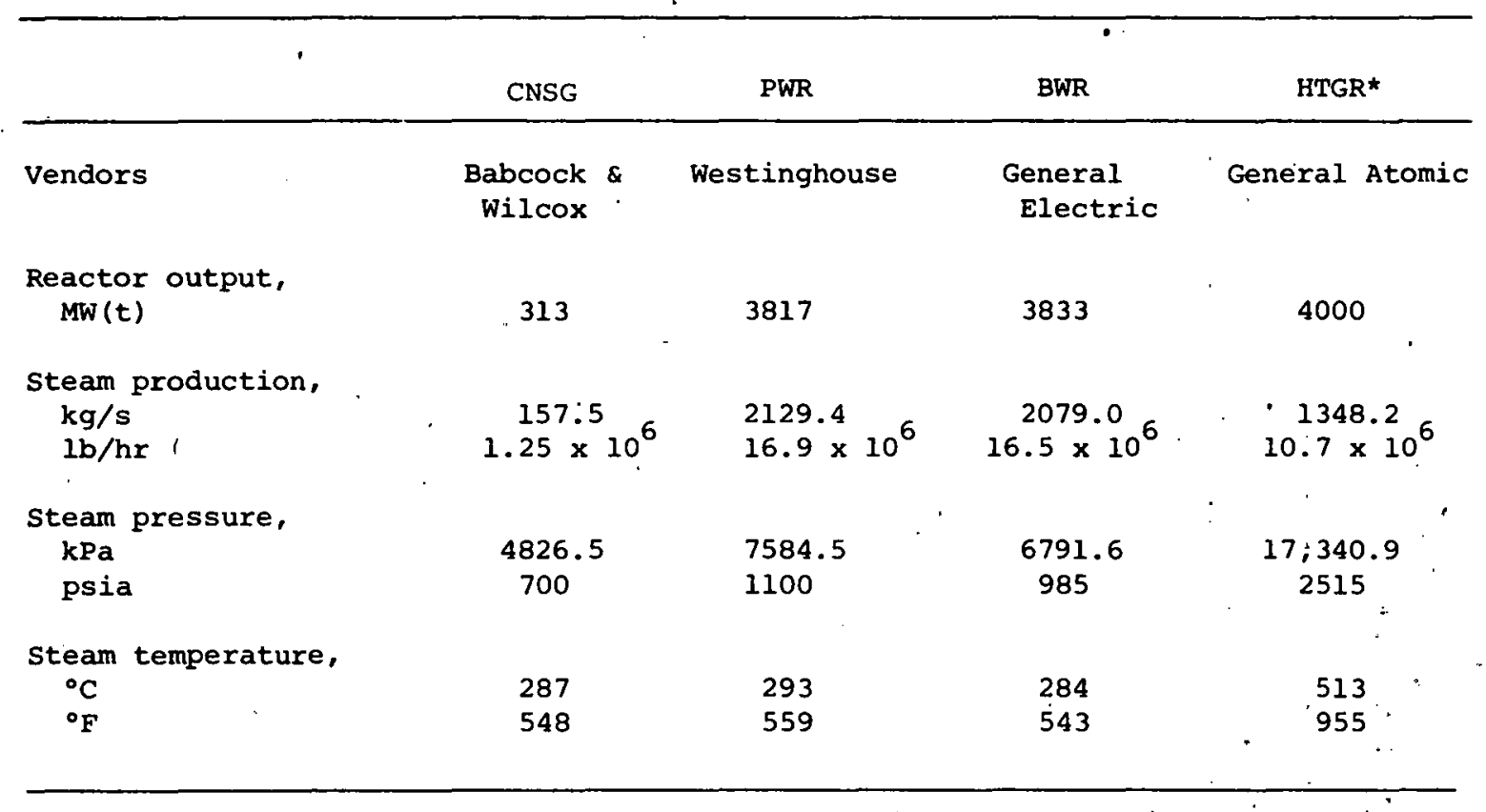

*Proposed.

Source: E. L. Cox, "Design and Operation of Nuclear Power Plants for Process. Heat Application," Proceedings of the First National Topical Meeting on Nuclear Process Heat Applications, Los Alamos, . New Mexico, October 1974, p. 90. 


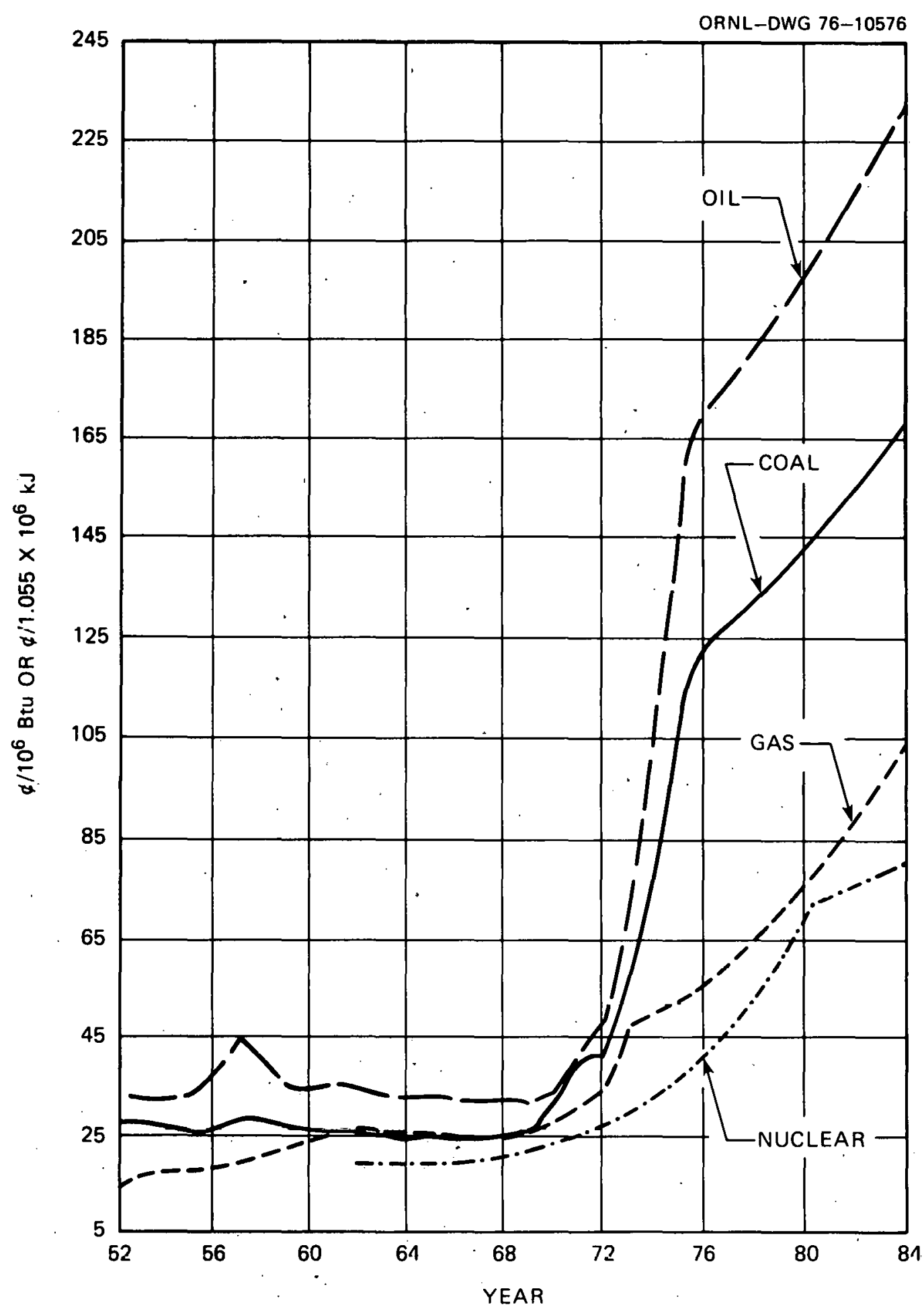

Source: An Analysis of Current Trends in Nuclear and Fossil Powered Generation Costs. Merril J. Whitman, Energy Research and Development Administration, Washington, D. C. (June 1975).

F1g. 1. Average annual cost of fuels burned for electrical generation in the United States 1952-1984 (constant 1975 dollars). 
STUDY RESULTS FOR THE CHEMICAL INDUSTRY

A large percentage of responses to the questionnaire ( 17 out of 29 , or 59\%) came from the chemical industry. These 17 plants represented a total steam consumption of $1741 \mathrm{~kg} / \mathrm{s}\left(13.819 \times 10^{6} \mathrm{lb} / \mathrm{hr}\right)$, or an equivalent of $127.71 \times 10^{12} \mathrm{~kJ} /$ year $\left(121.05 \times 10^{12} \mathrm{Btu} /\right.$ year $) .^{*}$ By utilizing 1971 data as a basis of comparison, it is possible to determine the extent to which the 17 plants in the survey represent total chemical industry steam consumption: ${ }^{5}$

Total average hourly steam consumption by the 17 plants $=1741 \mathrm{~kg} / \mathrm{s}$ $\left(13.819 \times 10^{6} \mathrm{lb} / \mathrm{hr}\right)$.

Total average $\mathrm{kJ}$ equivalent $=(1741 \mathrm{~kg} / \mathrm{s}) \times\left(3.1536 \times 10^{7} \mathrm{~s} /\right.$ year $)$ $x(2326.23 \mathrm{~kJ} / \mathrm{kg})=127.71 \times 10^{12} \mathrm{~kJ} /$ year [or $\left.\left(13.819 \times 10^{6} \frac{\mathrm{lb}}{\mathrm{hr}}\right) \times 8760 \frac{\mathrm{hr}}{\text { year }} \times 1000 \frac{\mathrm{Btu}}{\mathrm{hr}}=121.05 \times 10^{12} \frac{\mathrm{Btu}}{\text { year }}\right]$.

Estimated industry-wide equivalent fuel consumption for steam production in 1971 (see Table $I$ and ref. 5) is $75 \%$ of all fuel energy :

$0.75\left(2279 \times 10^{12} \mathrm{~kJ} /\right.$ year $)=1709 \times 10^{12} \mathrm{~kJ} /$ year $\left[1620 \times 10^{12} \mathrm{Btu} /\right.$ year $]$. Sample size, or representativeness, of the 17 plants in the survey = $\frac{127.71 \times 10^{12}}{1.709 \times 10^{12}}(100) \simeq 7.5 \%$.

Respondents to the questionnaire were requested to provide data from plants that consumed large amounts of process steam. For this reason the 17 chemical plants represent approximately $7.5 \%$ of total industry steam production, which is believed to be a "good" sample for purposes of this study. While a comparison of 1973 to 1974 sample data with 1971 industrywide data does not provide a highly accurate measure of how well the 17 plants represent the chemical industry, it does, nevertheless, give a rough indication of the "cross-section" of steam production and consumption patterns reported here.

A conservative conversion factor of $2326.23 \mathrm{~kJ} / \mathrm{kg}$ (1000 Btu/lb of steam) was used because of considerable variation in steam temperatures and pressures. 
Energy consumption data for the 17 plants are shown in Table $4 . \mathrm{Be}-$ cause this study is centered on various aspects of industrial steam requirements, chemical plants have been numbered in order of decreasing total steam production in Table 4. This identification number is used throughout this section to ensure the anonymity of the respondent. From Table 4 it can be seen that the 17 plants produced steam in amounts ranging from a high of $424.6 \mathrm{~kg} / \mathrm{s}$ to a low of $8.2 \mathrm{~kg} / \mathrm{s}(3,370,000$ to $65,000 \mathrm{lb}$ of steam $/ \mathrm{hr})$. The average steam consumption at a "typical" plant was $102.4 \mathrm{~kg} / \mathrm{s}(812,880 \mathrm{lb} / \mathrm{hr})$.

The second column of Table 4 indicates the total rate of energy consumption, including purchased electrical energy and/or steam energy. To maintain a single basis of comparison throughout the study, electrical energy expressed in kilowatts ( $\mathrm{kW}$ ) was converted to a rate of steam flow by this relationship:

\section{$I \mathrm{~kW}=0.000428 \mathrm{~kg} / \mathrm{s}(1 \mathrm{~kW}=3.4 \mathrm{lb}$ of steam $/ \mathrm{hr}$ and $294 \mathrm{~kW} \simeq 1000 \mathrm{Ib}$ of steam/hr).}

Total consumption of steam, in pounds per hour, is given in the third column of Table 4. (See footnote at bottom of Table 4 to convert pounds of steam per hour to $\mathrm{kg} / \mathrm{s}$.) Numbers of this column include steam produced at a central boiler station, at waste heat recovery boilers and by exothermic reactors. It is interesting to note that even though most of the chemical plants in the sample are relatively large in terms of their steam consumption, a sizable fraction of their steam-supply systems is located at one central boiler station. This is apparent from the fourth column of Table 4. In fact, only four chemical plants have more than 15\% of their steam requirements provided from noncentralized facilities. As seen in the last column of this table, steam used for process heat applications accounts for at least half of all steam consumption at 10 of the 17 plants.

A general summary of the types of fuel utilized and boiler capacities at each plant is provided in Table 5. The number of coal-burning boilers, for example, at plant 9 is seven, and their combined nameplate capacity (shown in parentheses) is $140 \mathrm{~kg} / \mathrm{s}(1,117,0001 \mathrm{~b}$ of steam per hour). Total breakout of fuel by type for the 17 plants, according to nameplate capacities, is: natural gas, 30.4\%; coal, 38.5\%; oil, $20.7 \%$, and other, $10.4 \%$. The "other" category includes process heat recovery units, and larger chemical plants tend to produce appreciable amounts of steam by this means. 
Table 4. Enercy production and cossumption data for seventeen chemical plants in the survey (Most data Zor the period, July 1, 1973-June 30, 1974)

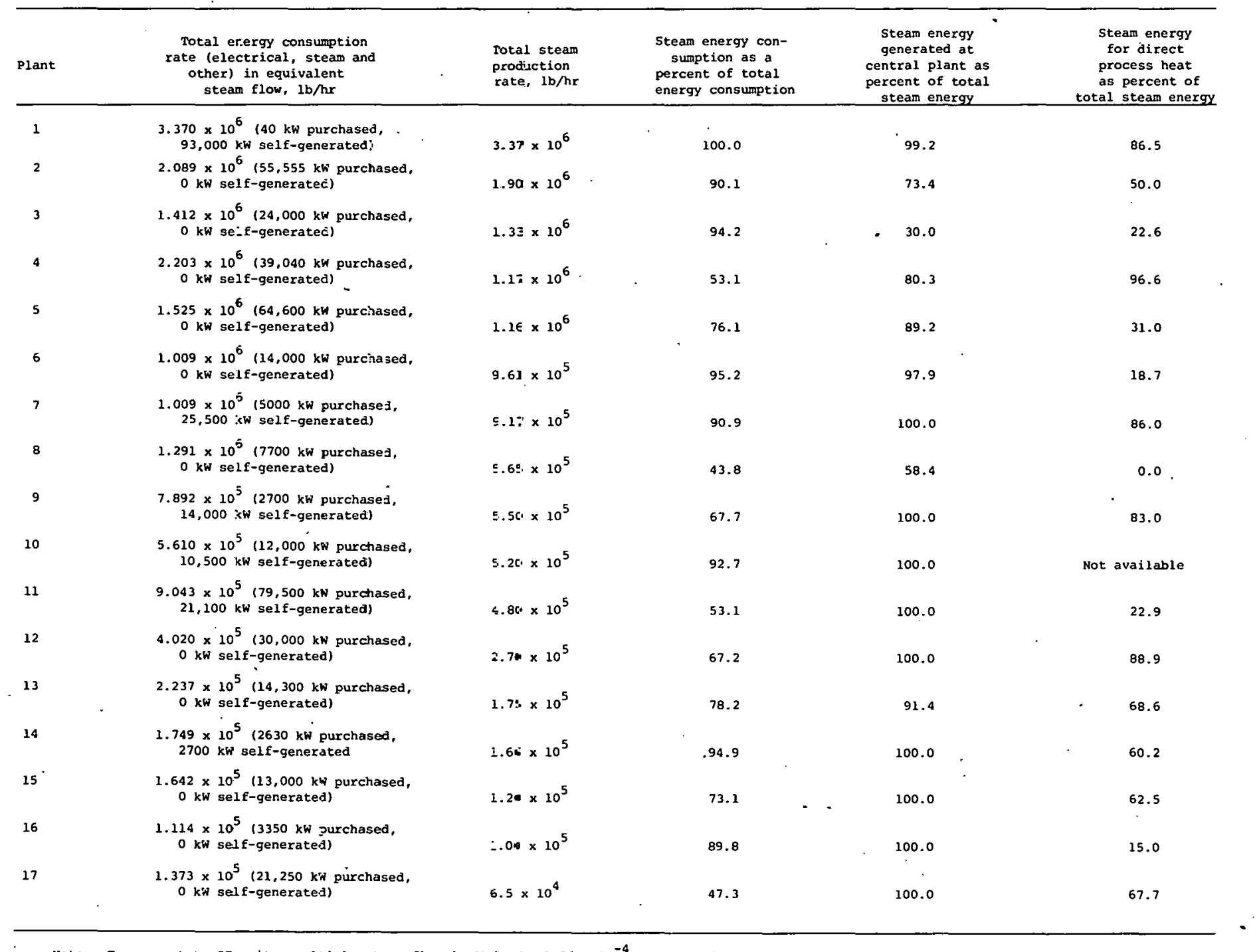

Note: To convert to SI units, multiply steam flow in $1 \mathrm{~b}, \mathrm{hr}$ by $1.26 \times 10^{-4}$ to get $\mathrm{kg} / \mathrm{s}$. 
Table 5. Summary of numbers of boilers and their associated nameplate capacities $\left(10^{3} \mathrm{lb}\right.$ of steam/hr) for seventeen chemical plants in the survey

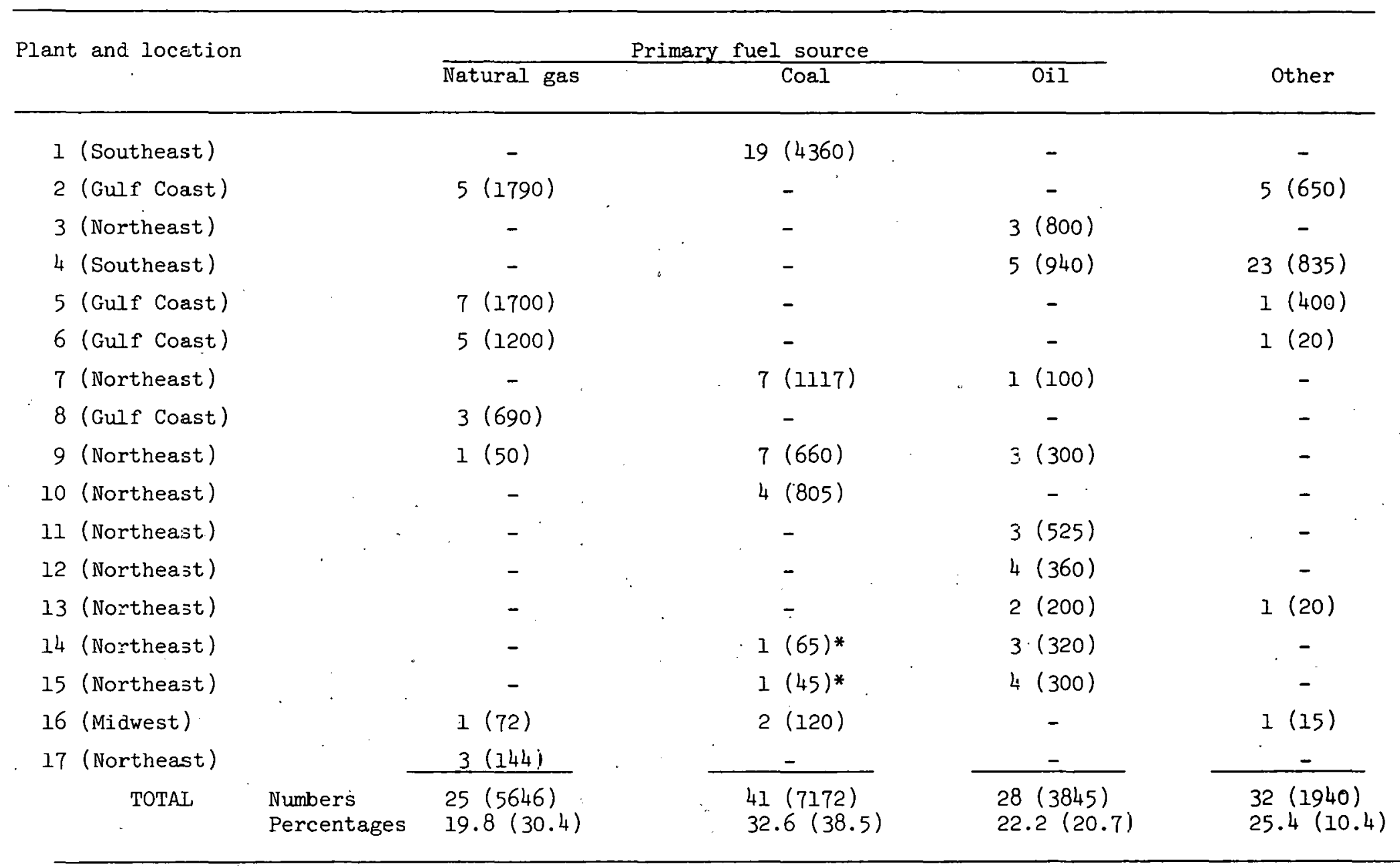

*These boilers were on standby and not used during the survey period.

NOTE: To convert to SI units, multiply steam flow in $1 \mathrm{~b} / \mathrm{hr}$ by $1.26 \times 10^{-4}$ to get $\mathrm{kg} / \mathrm{s}$. 
When these results are compared with those of a nationwide study conducted by the Stanford Research Institute (SRI), ${ }^{6}$ it is discovered that there are appreciable differences in fuel consumption patterns:

\begin{tabular}{lcc} 
& $\begin{array}{c}\text { SRI study }(1971)^{7} \\
(\%)\end{array}$ & $\begin{array}{c}\text { Present } \\
\end{array}$ \\
\cline { 2 - 3 } Natural gas & 68 & 30.4 \\
Coal and coke & 22 & 38.5 \\
Oil & 10 & 20.7 \\
Other & - & 10.4
\end{tabular}

While these differences are possibly due to sampling error, they are most likely caused by the fact that 12 of the 17 plants are located in the Northeast and Southeast (see Table 5) and therefore have relatively easy access to Appalachian coal sources. Furthermore, differences may be partly due to recent federal efforts at limiting the use of natural gas and imported fuel oil.

Summaries of detailed steam boiler data are given in Tables 6 and 7 . of the steam-generation units included in the survey, a significant number of them appear to be likely candidates for replacement in the near future. Over $60 \%$ of the units have been in use for at least 10 years, and more than $40 \%$ have been in use for over 20 years. However, further analysis reveals that most of the larger boilers (i.e., at least $31.5 \mathrm{~kg} / \mathrm{s}$ or $250,000 \mathrm{lb}$ of steam per hour) operating at temperatures and pressures in excess of $288^{\circ} \mathrm{C}\left(550^{\circ} \mathrm{F}\right)$ and $4137 \mathrm{kPa}$ (600 psig) have been in service for 10 years or less. These data support the general observation made earlier that many companies believe that for a given level of steam requirement the economic advantages obtained through installation of larger steamgenerating systems outweigh the higher reliability obtained through utilization of many smaller boilers with equivalent capacity. While a study of forced outage rate as a function of unit size was not included as part of this survey, the interested reader can find additional information in publication number $75-50$ of the Edison Electric Institute. ${ }^{8}$

The prospects of using light water reactors (LWRs) to replace existing steam supply systems at chemical plants included in this survey appear good. 
Table 6. Boiler pressure breakouts for seventeen chemical plants in survey

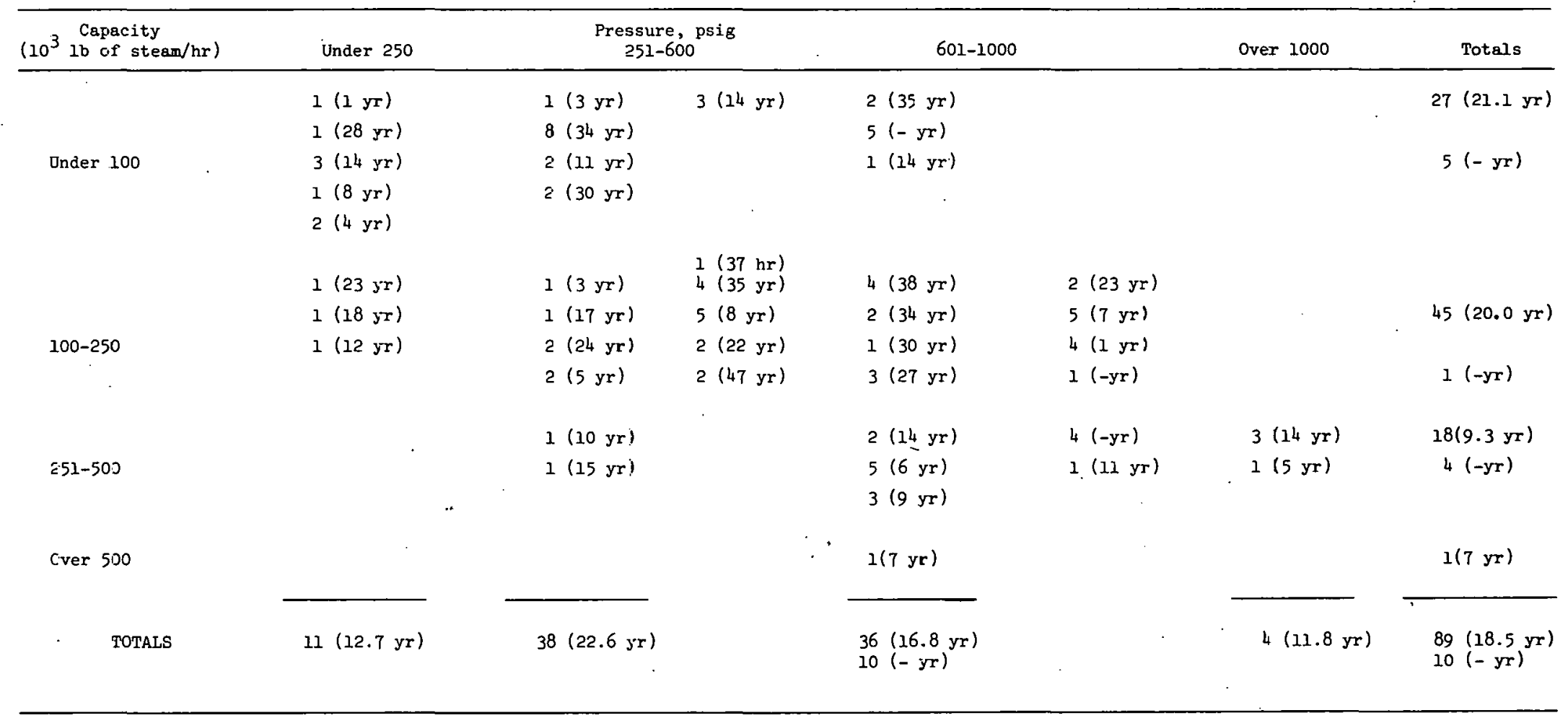

Note 1: Average age of boilers in parentheses, where (-) indicates that data were not available.

Note 2: To convert to $\subseteq I$ units, multiply steam flow in $1 \mathrm{~b} / \mathrm{hr}$ by $1.26 \times 10^{-4}$ to get $\mathrm{kg} / \mathrm{s}$ and muitiply pressure in $1 \mathrm{~b} / \mathrm{in} .^{2}$ by 6.895 to get $\mathrm{kPa}$. 
Table 7. Boiler temperature breakouts for seventeen chemical plants in survey

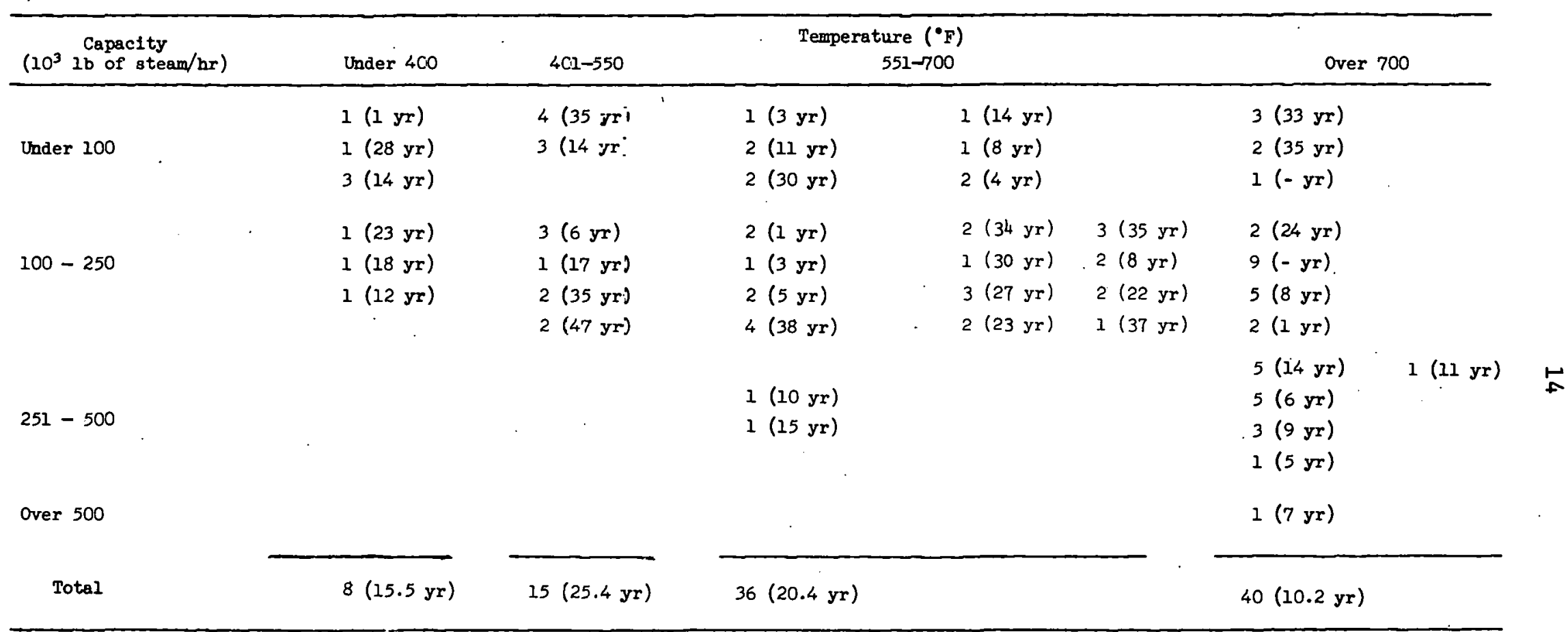

Note 1: Average age of bollers in parentheses, where $(-)$ indicates thet data were not available.

Note 2: To convert to SI units, milltiply steam flov in $1 \mathrm{~b} / \mathrm{hr}$ by $1.26 \times 10^{-4}$ to get $\mathrm{kg} / \mathrm{s}$ and determine temperature in degrees Celsius as follows, $t_{C}^{\circ}=\left(t_{F}^{\circ}-32\right) \div 1.8$. 
This statement is based on the findings of a Dow Chemical Company study 9 . of five major industries representing $75 \%$ of the total industrial steam consumption in the United States: Paper (S.I.C.26), Chemicals (S.I.C.28), Petroleum (S.I.C.29), Rubber (S.I.C.30), and Primary Metals (S.I.C.33).

In the Dow report this conclusion was drawn relative to steam temperature requirements for industrial processes:

"Process steam applications within the industries studied involve temperatures from about $100^{\circ} \mathrm{F}$ up to about $450^{\circ} \mathrm{F}$. Although steam is often produced at temperatures above $450^{\circ} \mathrm{F}$, the high temperature/high pressure steam is first used for electrical power generation and then extracted at lower pressures for process heat. Also, much of the steam use in the $450^{\circ} \mathrm{F}$ temperature range is in turbines or reciprocating engines, driving pumps, compressors, etc. These applications can and often will be converted to electrical drive as steam costs increase. Thus, we estimate that at least $85 \%$ of the industrial steam heat requirement is below $400^{\circ} \mathrm{F}$ and within the range available from conventional nuclear light water reactors."

A means of producing prociess steam in quantities that match the needs of several of the larger chemical plants listed in Table 4 is with the Consolidated Nuclear Steam Generator (CNSG). The CNSG is a special-purpose pressurized water reactor rated at $313 \mathrm{MW}(t)$ that has been developed by the Babcock and Wilcox Company. Major reactor parameters of interest were shown earlier in Table 3.

Many of the chemical plants use steam in a number of sequential steps, each of which removes a portion of the thermal energy available. As noted above in the Dow study, the first step in some of these operations is frequently the generation of electrical power. This could also be accomplished by utilizing lower-pressure turbines as is done in commercial LWR power stations. Additionally, if high temperature steam is required for a limited number of applications, a fossil or by-product fueled superheat boiler could be included as part of the CNSG steam-generation system.

From Table 4 it can be seen that six of the 17 chemical plants generate a large fraction of their electrical power requirements. This may partially explain the preponderance of high boiler temperatures shown in Table 7 and the difference between results of the present study and the Dow statement above.

The most important information from questionnaire responses concerned the overall reliability of steam-supply systems at the 17 chemical plants. 
In view of the definition of reliability given earlier (page 2), an analysis was made of safety margins (on-line steam-generating capacity less actual steam production) and percent of clock time that each plant was unable to meet scheduled steam production. Information regarding these two indicators of reliability was taken directly from questionnaire responses.

Results of analyzing data in Sections 1 and 2 of the questionnaire are presented in Table 8 . Safety margins at each plant were determined by subtracting line D of Table 8 from line $B$. A more realistic evaluation of the safety margin is ( $B-E)$, but in most responses to the questionnaire no distinction was made between lines $D$ and $E$.

Interesting characteristics of the safety margin are calculated in lines $\mathrm{H}$ and $\mathrm{J}$ of Table 8 . Line $\mathrm{H}$ indicates that margins of safety, expressed as percentages of actual steam usage, are on the average about 44\%. They range from 4.2 to $141.0 \%$. From line $J$ it can be seen that safety margins as a percentage of the largest on-line steam-generator range from 11.4 to $140.0 \%$. Eleven out of 17 plants had safety margins that were $80 \%$ or more of the largest on-line unit. This indicates that high reliability has been sought at the expense of having considerable amounts of excess capacity available.*

The "unreliabilities" of steam-supply systems were computed in two parts: (1) as a percent of clock time that the system was unable to meet scheduled steam production because of equipment outages, and (2) as a percent of clock time that scheduled steam production was curtailed due to nonequipment related outages (planned and unplanned). As can be seen from line $\mathrm{N}$ of Table 8 , the overall reliability of steam-supply systems (one minus the unreliability shown in line N) ranges from 100 to $89 \%$. Notice that downtime caused by vacation and/or turnaround is excluded from the unreliability in line $N$.

To highlight pertinent information regarding unreliabilities of steamsupply systems now in operation, a summary of Table 8 has been prepared

* Plant No. 11 has a small safety margin and a highly reliable steamsupply. system because a sizable fraction of its capacity is operated in parallel with a nearby electrical utility company. This arrangement works to the advantage of both companies. 
Table 8. Process steam system capacity, consumption rate and reliability for chemical plants in the survey

\begin{tabular}{|c|c|c|c|c|c|c|c|c|c|c|c|c|}
\hline \multirow[b]{2}{*}{ Item of data } & \multicolumn{11}{|c|}{ Plant } & \multirow{2}{*}{$\frac{\cdot}{12}$} \\
\hline & $\overline{1}$ & 2 & $3^{5}$ & 4 & 5 & 6 & 7 & 8 & 9 & 10 & 11 & \\
\hline $\begin{array}{l}\text { A. Average Installed capacity, } \\
10^{3} \mathrm{lb} \text { of } \mathrm{steam} / \mathrm{hr}\end{array}$ & 4360 & 2440 & 800 & 1595 & 1700 & 1200 & 1220 & 690 & 780 & 805 & 525 & 360 \\
\hline $\begin{array}{l}\text { B. Average on-line capacity, } \\
10^{3} \mathrm{lb} \text { of steam } / \mathrm{hr}\end{array}$ & 3700 & 2320 & 758 & 1450 & 1475 & 1190 & 1155 & 659 & $6 \pi 0$ & 764 & 500 & 330 \\
\hline $\begin{array}{l}\text { c. Average on-line capacity, } \\
\text { as percentage of A. }\end{array}$ & 84.8 & 95.1 & 94.8 & 91.0 & 86.8 & 99.2 & 94.7 & 95.5 & 85.9 & 94.9 & 95.2 & 91.7 \\
\hline $\begin{array}{l}\text { D. Average actual steam usage, } \\
10^{3} \mathrm{lb} \text { of steam } / \mathrm{hr}\end{array}$ & 3300 & 1930 & 390 & 1170 & 1160 & 960 & 917 & 565 & 550 & 520 & 480 & 270 \\
\hline $\begin{array}{l}\text { E. Average scheduled steam } \\
\text { usage, } 10^{3} \mathrm{lb} / \mathrm{hr}\end{array}$ & 3300 & 1900 & 400 & 1203 & 1230 & 960 & 917 & 580 & 600 & 530 & 480 & 280 \\
\hline $\begin{array}{l}\text { F. Average actual steam usage, } \\
\text { as percentage of B }\end{array}$ & 89.2 & 81.9 & 51.5 & 80.7 & 78.6 & 80.7 & 79.4 & 85.7 & 82.1 & 68.1 & 96.0 & 84.8 \\
\hline $\begin{array}{l}\text { c. Average safety margin, } \\
\text { Item B - Item D }\end{array}$ & 400 & 420 & 368 & 280 & 315 & 230 & 238 & 94 & 120 & $2 L b$ & 20 & 50 \\
\hline $\begin{array}{l}\text { H. Average safety margin, } \\
\text { as percentage of } \mathrm{D}\end{array}$ & 12.1 & 22.1 & 94.4 & 23.9 & 27.2 & 24.0 & 25.9 & 16.6 & 21.8 & 46.9 & 4.2 & 18.5 \\
\hline $\begin{array}{l}\text { I. Largest unit on-line } \\
\text { (i) } 10^{3} \mathrm{lb} \text { of stegm/hr } \\
\text { (ii) avg. percentege of } B\end{array}$ & $\begin{array}{l}430 \\
11.6\end{array}$ & $\begin{array}{l}400 \\
17.2\end{array}$ & $\begin{array}{l}400 \\
52.8\end{array}$ & $\begin{array}{l}200 \\
13.8\end{array}$ & $\begin{array}{l}550 \\
37.3\end{array}$ & $\begin{array}{l}250 \\
21.0\end{array}$ & $\begin{array}{l}267 \\
23.1\end{array}$ & $\begin{array}{l}230 \\
34.9\end{array}$ & $\begin{array}{l}125 \\
18.7\end{array}$ & $\begin{array}{l}350 \\
45.8\end{array}$ & $\begin{array}{l}175 \\
35.0\end{array}$ & $\begin{array}{l}100 \\
30.3\end{array}$ \\
\hline $\begin{array}{l}\text { J. Safety margin as percentage } \\
\text { of largest unit or-line (I) }\end{array}$ & 93.0 & 205.0 & 92.0 & 240.0 & 57.3 & 100.0 & 89.0 & 40.9 & 96.0 & 69.7 & 11.4 & 50.0 \\
\hline $\begin{array}{l}\text { K. Percent of t1me steam supply } \\
\text { unable to meet scheduled re- } \\
\text { quirements (E) due to random } \\
\text { equipment outages }\end{array}$ & 0.8 . & 0 & 0 & 2.4 & 9.0 & 0 & 0.8 & 0 & 3.8 & 6.8 & 0 & 0 \\
\hline $\begin{array}{l}\text { L. Percent of time. scheduled } \\
\text { steam production }(E) \text { was cur- } \\
\text { tailed due to nonequipment } \\
\text { related outages }\end{array}$ & 0 & 0.5 & 1.4 & 0 & 2.0 & 0.5 & 0 & 1.2 & 2.0 & 0 & 0 & 1.2 \\
\hline $\begin{array}{l}\text { M. Percent of time plant was } \\
\text { completely shut down for } \\
\text { scheduled vacatior or plant } \\
\text { turnaround }\end{array}$ & 0 & 0 & 0 & 0 & 0. & 0 & 0 & 2.5 & 1.0 & 1.1 & 0 & 3.8 \\
\hline $\begin{array}{l}\text { N. Total percent of time sched- } \\
\text { uled steam production was cor- } \\
\text { talled (1tem } \mathrm{K}+1 \text { tem L) }\end{array}$ & 0.8 & 0.5 & 1.4 & 2.4 & 11.0 & $0.5:$ & 0.8 & 1.2 & 5.8 & 6.8 & 0 & 1.2 \\
\hline
\end{tabular}

-Steam data avallable only for cenoral power plant.

Note: To convert to SI units, mul=iply steam s.low in $1 \mathrm{~b} / \mathrm{hr}$ by $1.26 \times 10^{-4}$ to get $\mathrm{kg} / \mathrm{s}$. 
Table 8. fcontinued

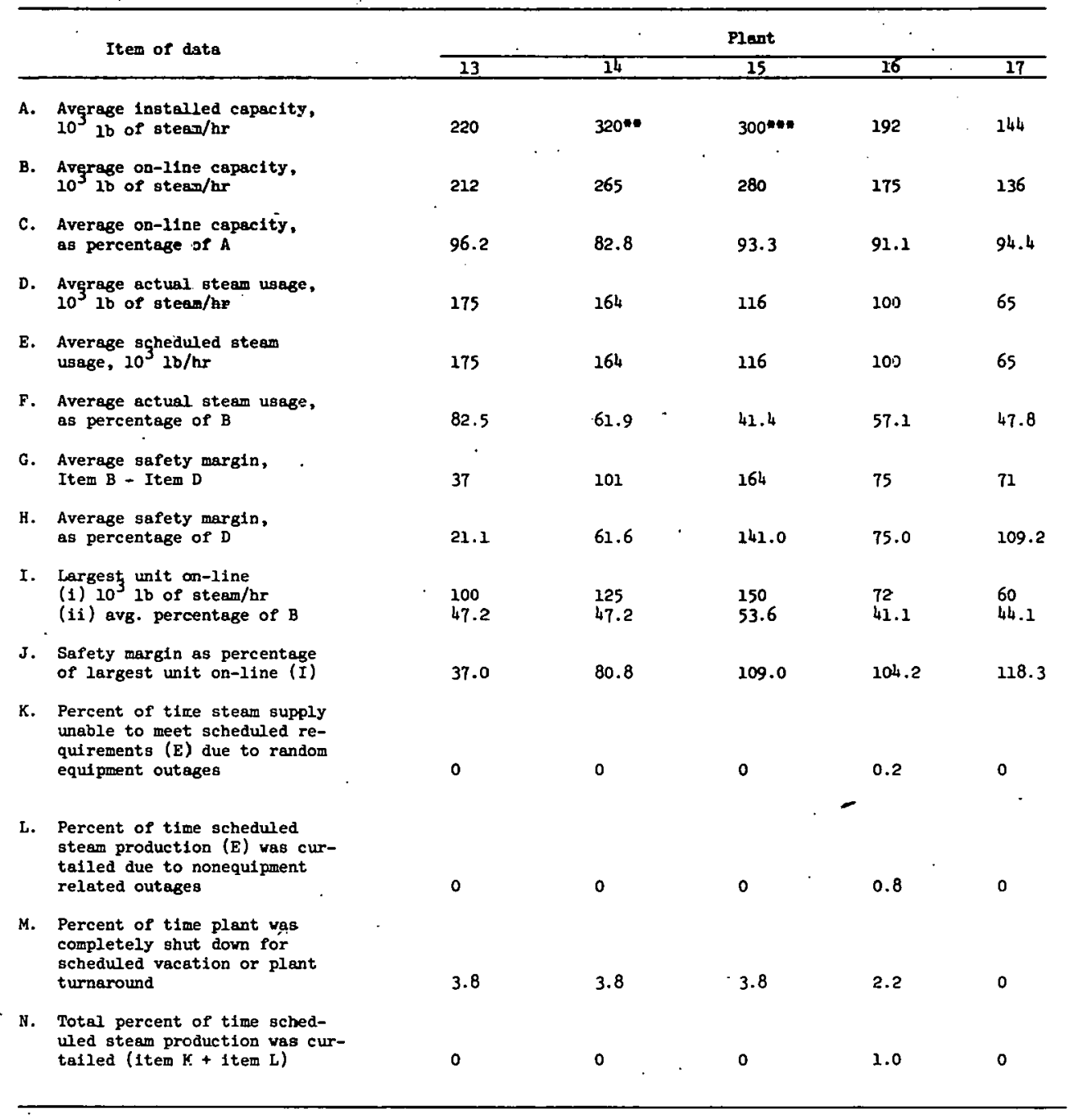

* Does not include $65,000 \mathrm{2b} / \mathrm{hr}$ standby boiler.
*"Does. not include 45,000 $\mathrm{lb}$; hr standby boiler.

Note: To corvert to SI units, multiply steerr flow in $1 \mathrm{~b} / \mathrm{hr}$ by $1.26 \times 10^{-4}$ to get $\mathrm{kg} / \mathrm{s}$. 
and is included as Table 9. Here there are four parameters of the unreliability of a plant: two are related to the safety margin and the others are related to failure of the steam source in meeting scheduled requirements for steam. On the average the unreliability was about $2.0 \%$, but 9 of the 17 plants were able to meet scheduled demand for steam better than $99 \%$. of the time (unreliabilities less than 1.0\%). On the other hand, three plants were not able to meet scheduled steam requirements better than $95 \%$ of the time. Thus plants in the survey tended to be divided into two groups; namely, highly reliable and "medium" reliable.

Reasons for these two groupings can be clearly seen by referring to Table 10. In this table the magnitude and duration of loss in capacity are described for the 17 plants. A qualitative rating of the severity of the outage is given in column 3. Here a "I" represents the ideal condition of no production curtailment due to boiler outages and a " $O$ " indicates a total plant shutdown.

The smaller plants (12,13,14, 15, and 16) have a policy of complete shutdown during vacation periods, whereas the larger plants do not. From lines $G$ and $J$ of Table 9, it could not be concluded that smaller steam users had less reliable steam-supply' systems than the larger plants because of the fact that their safety margins were proportionately less. If vacation periods had been included as "planned, nonequipment related outages". in computing line $\mathrm{N}$ of Table 9, the average reliability of all plants would have been $96.7 \%$. However, if vacation time is neglected . Table 9 shows that sources of process steam are on the average $98 \%$ reliable based on results of the present survey. This translates into the following statement: "On the average, product losses (production curtailments) due to steam outages occur for 7 days each year." From another viewpoint it might be said that all products met their sales plans except for 7 days production because of interruptions in a continuous supply of steam energy. Judging from Tables 8 and 9, an economic target level of 2 days (or less) of curtailed production per year could be viewed as an "ideal" criterion to be met by steam supply systems in large chemical plants. This corresponds to a $99.5 \%$ reliable supply of steam. 
Table.9. Sumary of reilatility measures for seventeen chemical plants in survey

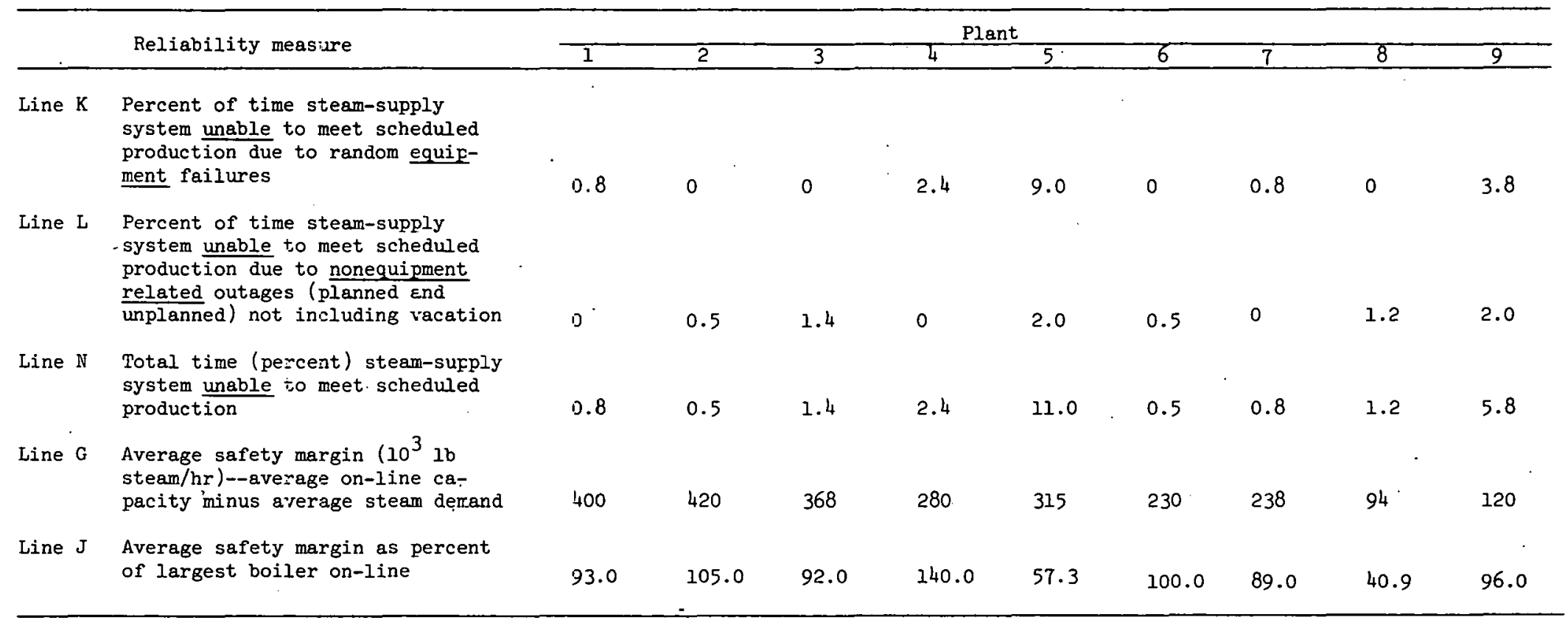


Table 9. (continued)

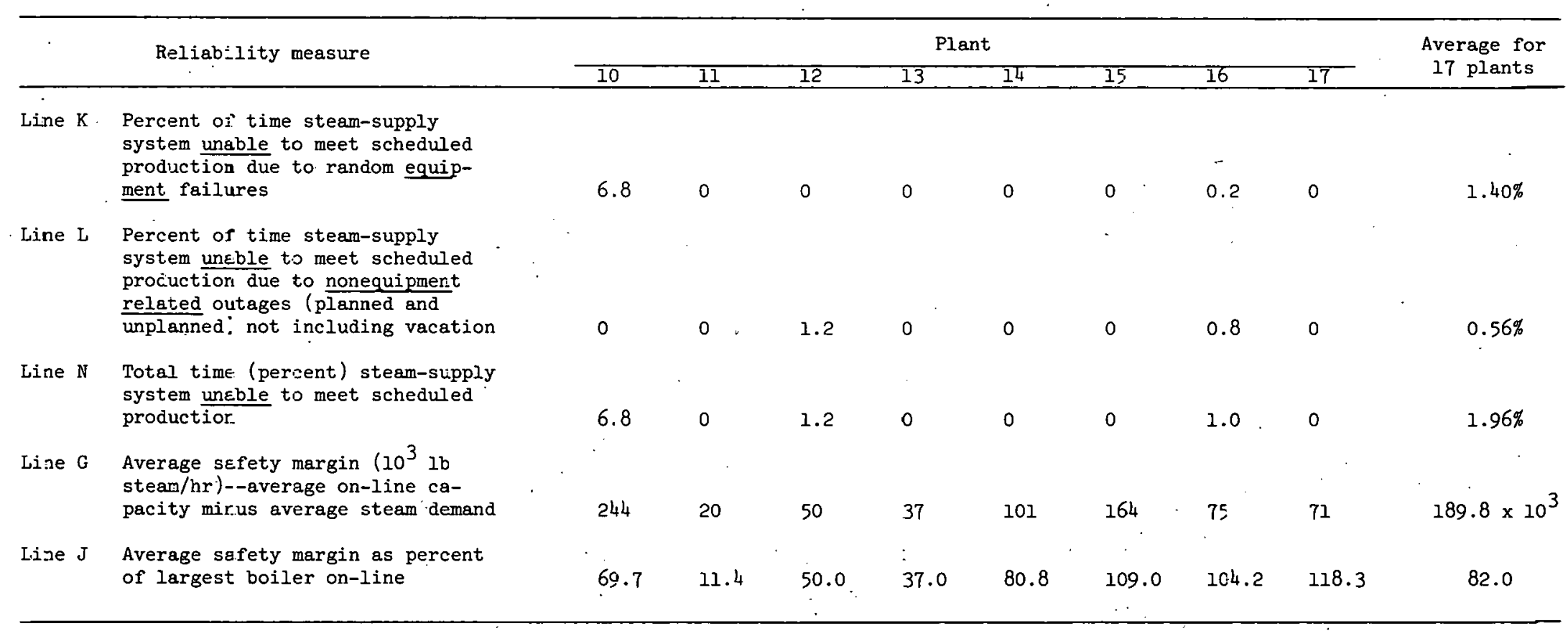


Table 10. Number and severity of outages represented by lines $K, L$, and $M$ of Table 8

\begin{tabular}{|c|c|c|}
\hline Plant & $\begin{array}{l}\text { Magnitude of capacity loss } \\
\text { (1b steam/hr) and } \\
\text { duration of the loss }\end{array}$ & $\begin{array}{l}\text { Severity of outage, } \\
\text { (Available capacity online } \\
\text { during the outage } \\
\div \text { line E) }\end{array}$ \\
\hline 1 & $\begin{array}{l}\text { Loss of approximately } 8 \% \text { of rated capacity due to boiler failures. } \\
\text { Occurs } 2-3 \text { times } / y \text { for } 1 \text { day each. }\end{array}$ & $\sim 0.95$ \\
\hline$\cdot 2$ & Complete shutdom due to violent storms (averages 2 days $/ y r$ ). & 0 \\
\hline 3 & $\begin{array}{l}\text { Down completely an average of } 5 \text { days/yr because of electrical } \\
\text { failures. }\end{array}$ & 0 \\
\hline 4 & $\begin{array}{l}\text { Down } 16 \mathrm{hr} \text { to zero capacity, down } 40 \mathrm{hr} \text { to } 1 / 3 \text { of rated } \\
\text { capacity and down } 156 \mathrm{hr} \text { to } 3 / 5 \text { of rated capacity. }\end{array}$ & $\sim 0.50$ \\
\hline 5 & $\begin{array}{l}\text { Fourteen outages reported that resulted in curtailed, scheduled } \\
\text { steam production. They range. from } 2 \% \text { loss of rated capacity } \\
\text { for a few hours to } 100 \% \text { loss for } 8-9 \text { days. }\end{array}$ & $\sim 0.60$ \\
\hline 6 & Complete shutdown due to violent storms (average 2 days $/ y r$ ). & 0 \\
\hline 7 & $\begin{array}{l}\text { Complete shutdowns due to random outages, operator mistakes } \\
\text { (average } 3 \text { days } / y r \text { ). }\end{array}$ & 0 \\
\hline 8 & $\begin{array}{l}\text { Nine day turnaround for entire plant once per year. Power } \\
\text { losses and violent storms shut plant down an average of } 4.5 \\
\text { days per year. }\end{array}$ & $\sim 0.05$ \\
\hline 9 & $\begin{array}{l}\text { Complete shutdowns for maintenance and labor dispute. Down } \\
2 \text { weeks to } 70 \% \text { of rated capacity due to accident. }\end{array}$ & $\sim 0.35$ \\
\hline 10 & $\begin{array}{l}\text { Complete shutdown for maintenance on } 2 \text { occasions per year } \\
\text { ( } 48 \text { hours each). Down } 5 \% \text { or less of rated capacity for } 25 \\
\text { days during the year surveyed ( } 4 \text { curtallments). }\end{array}$ & $\sim 0.9$ \\
\hline .11 & No outages reported that currealled scheauled steam prouucion. & $\mathrm{N} / \mathrm{A}$ \\
\hline 12 & $\begin{array}{l}\text { Complete shutdowns for two-week vacation (once/yr) and tor } \\
\text { random interruptions that average } / \text { days/yr). }\end{array}$ & 0 \\
\hline 13 & Complete shutdown for two-week vacation (once/yr). & 0 \\
\hline 14 & Complete shutdown for two-week vacation, once per year. & 0 \\
\hline 15 & Cumplete shutdown for two-week vacation, onec per ycar. & 0 \\
\hline 16 & $\begin{array}{l}\text { Complete shutdown for } 8 \text { days of vacation (2 separate occasions). } \\
\text { An average of } 3 \text { days/yr curtailed production due to power } \\
\text { failures and strikes. }\end{array}$ & $\sim 0.2$ \\
\hline 17 & No outages reported that curtailed scheduled steam production. & N/A \\
\hline
\end{tabular}


STUDY RESULTS FOR PETROLEUM REFINERIES

Data were obtained for nine refineries (seven different petroleum companies) that in 1973 to 1974 had a total steam consumption of $1675 \mathrm{~kg} / \mathrm{s}$ $\left(13.293 \times 10^{6} \mathrm{lb} / \mathrm{hr}\right)$, which is equivalent to $122.85 \times 10^{12} \mathrm{~kJ} /$ year $(116.45$ $x 10^{12} \mathrm{Btu} /$ year). ${ }^{*}$ To determine what percentage of total refinery steam consumption these nine refineries represent, data from the study were used in making the following estimate:

Total average $\mathrm{kJ}$ equivalent $=(1675 \mathrm{~kg} / \mathrm{s}) \times\left(3.1536 \times 10^{7} \mathrm{~s} /\right.$ year $)$ $\mathrm{x}(2326.23 \mathrm{~kJ} / \mathrm{kg})=1.22 .87 \times 10^{12} \mathrm{~kJ} /$ year $\left[\left(13.293 \times 10^{6} \mathrm{lb} /\right.\right.$ year $)$ x $8760 \mathrm{hr} /$ year $\times 1000 \mathrm{Btu} / \mathrm{lb}=116.45 \times 10^{12} \mathrm{Btu} /$ year $]$.

Estimated industry-wide fuel consumption for steam production in 1971 (ref. 5) $=1119 \times 10^{12} \mathrm{~kJ} /$ year $\left(1061 \times 10^{12} \mathrm{Btu} /\right.$ year $)$.

Projected increase for total use of heat and power by the industry is $1.8 \%$ /year over the 1971 to 1980 period (ref. 10), so estimated fuel consumption for steari production in 1973 to $1974=\left(1119 \times 10^{12}\right.$ $\mathrm{kJ} /$ year $) \times(1.018)^{3}=1180 \times 10^{12} \mathrm{~kJ} /$ year.

Percent representation of the nine refineries in the survey $=$ $\frac{122.87 \times 10^{12} \mathrm{~kJ} / \text { year }}{1180 \times 10^{12} \mathrm{~kJ} / \text { year }}(100) \simeq 10.4 \%$.

A $10.4 \%$ sampling of refinery steam consumption in the present study is regarded as an excellent cross-section of the petroleum refining industry. Accordingly, credible conclusions concerning steam system reliabilities at refineries can be drawn from data submitted by the nine refineries. This energy-intensive industry accounts for approximately $9.4 \%$ of energy purchased by all manufacturing industries, so energy characteristics reported in this section represent around $1 \%$ of total manufacturing energy purchases. 10

*Again, a conservative conversion factor of $2326.23 \mathrm{~kJ} / \mathrm{kg}$ (1000 Btu/lb of steam) was utilized because of considerable variation in refinery steam pressures and temperatures. 
Energy consumption data for the refineries are included in Table 11. Here it can be seen that the total steam consumption rate varied from a high of $551.3 \mathrm{~kg} / \mathrm{s}(4,375,000 \mathrm{lb} / \mathrm{hr})$ to a low of $39.2 \mathrm{~kg} / \mathrm{s}(31 \mathrm{l}, 000 \mathrm{lb} / \mathrm{hr})$. The "average" refinery used $186.1 \mathrm{~kg} / \mathrm{s}(1,477,000 \mathrm{lb}$ of steam $/ \mathrm{hr})$. Because this study is primarily concerned with reliability aspects of steam production systems, refineries have been numbered in Table 11 in order of deereasing total steam usage rates.

The second column of Table 11 shows the rates of energy consumption at each refinery, including electrical and steam energy purchased or sold." In addition, kilowatts of self-generated electrical power is listed. Four of the nine refineries generate substantial amounts of electricity. As in the case of the chemical companies, electrical energy expressed in kilowatts $(\mathrm{kW})$ has been converted to an equivalent rate of steam flow by this relationship:

$$
\begin{gathered}
I \mathrm{~kW}=0.000428 \mathrm{~kg} / \mathrm{s}(1 \mathrm{~kW}=3.4 \mathrm{lb} \text { of steam } / \mathrm{hr} \\
\text { and } 294 \mathrm{~kW} \simeq 1000 \mathrm{lb} \text { of steam } / \mathrm{hr}) .
\end{gathered}
$$

This was done to provide a common base for comparing energy consumption patterns at the nine refineries.

Average total steam production rates are given in column 3 and calculated as a percentage of total energy consumed in column 4. Entries in columns 2 and 3 are averages for 1973 to 1974 and thus include periods of time when energy usage was curtailed for reasons that are identified later. Moreover, steam data in columns 2 to 4 include steam obtained from one or more central boiler stations and from waste heat recovery units. Column 5 lists the percentage of steam raised at the central boiler station(s). The percentage of steam energy used for process heating is shown in column 6 .

A summary of types of fuel utilized and primary boiler capacities at each refinery is provided in. Table 12. Also indicated is the general 10cation of the refinery - most are situated east of the Mississippi River. The numbers in parentheses represent the nameplate capacities of boilers by fuel source. It can be seen that $25 \%$ of all boilers utilize fuel gas or natural gas, and these boilers burn $25 \%$ of all fuel based on nameplate capacities. On the other hand, $40 \%$ of the boilers use fuel oil and these boilers consume better than two-thirds of all fuel. None of the refineries *See footnote, Table 11 . 
Table 11. Energy production and consumption data for nine refineries in the survey (Most data for the period, July 1, 1973 - June 30, 1974)

\begin{tabular}{|c|c|c|c|c|c|}
\hline Refinery & $\begin{array}{l}\text { Iotal energy consumption } \\
\text { rate (electrical, steam and } \\
\text { other) in equivalent } \\
\text { steem flow, } 1 \mathrm{~b} / \mathrm{hr}\end{array}$ & $\begin{array}{l}\text { Total steam } \\
\text { production } \\
\text { rte, } 1 \mathrm{~b} / \mathrm{hr}\end{array}$ & $\begin{array}{l}\text { Steam energy con- } \\
\text { sumption as a } \\
\text { percent of total } \\
\text { energy consumption" }\end{array}$ & $\begin{array}{l}\text { Steam energy } \\
\text { generated at } \\
\text { central plant as } \\
\text { percent of total } \\
\text { steam energy }\end{array}$ & $\begin{array}{l}\text { Steam energy } \\
\text { for direct } \\
\text { process heat } \\
\text { as percent of } \\
\text { total steam energy }\end{array}$ \\
\hline 1 & $\begin{array}{r}4.893=10^{6}(145,000 \mathrm{~kW} \text { purcinased } \\
(35,000 \mathrm{~kW} \text { self-generated })\end{array}$ & $4.375 \times 10^{6}$ & 89.4 & 84.6 & 66.3 \\
\hline 2 & $\begin{array}{r}2.824 \times 10^{6}(7,000 \mathrm{~kW} \text { purchased }) \\
(54,000 \mathrm{~kW} \text { self-generated })\end{array}$ & $2.800 \times 10^{6}$ & 99.2 & 77.0 & 50.0 \\
\hline 3 & $\begin{aligned} 2.600 & =10^{6} \quad(800 \mathrm{~kW} \text { sold }) \\
& (4 \varepsilon, 800 \mathrm{~kW} \text { self-generated })\end{aligned}$ & $1.870 \times 10^{6}$ & 71.9 & 64.2 & 89.6 \\
\hline 4 & $\begin{array}{l}4.355 \times 10^{6}(30,280 \mathrm{~kW} \text { purchased }) \\
(2<, 500 \mathrm{~kW} \text { self-generated })\end{array}$ & $1.012 \times 10^{6}$ & 23.2 & 42.4 & 25.0 \\
\hline 5 & $\begin{array}{c}1.207 \times 10^{6}(31,300 \mathrm{~kW} \text { purchased }) \\
(0 \mathrm{~kW} \text { self-generated })\end{array}$ & $1.100 \times 10^{6}$ & 91.1 & 62.7 & 61.8 \\
\hline 6 & $\begin{array}{c}0.886 \times 10^{6}(31,100 \mathrm{~kW} \text { purchased }) \\
(0 \mathrm{~kW} \text { self-generated })\end{array}$ & $0.780 \times 10^{6}$ & 88.0 & 73.1 & 57.7 \\
\hline 7 & $\begin{array}{r}0.919 \times 10^{6}(50,000 \mathrm{~kW} \text { purchased }) \\
(0 \mathrm{~kW} \text { self-generated })\end{array}$ & $0.749 \times 10^{6}$ & 81.5 & 60.6 & 68.8 \\
\hline 8 & $\begin{array}{r}0.554 \times 10^{6}(16,985 \mathrm{~kW} \text { purchased }) \\
(0 \mathrm{~kW} \text { self-generated })\end{array}$ & $0.496 \times 10^{6}$ & 89.5 & 75.0 & 60.0 \\
\hline 9 & $\begin{array}{r}1.034 \times 10^{6}(4,800 \mathrm{~kW} \text { purchased }) \\
(0 \mathrm{~kW} \text { self-generated })\end{array}$ & $0.311 \times 10^{6}$ & 30.1 & 78.8 & 50.2 \\
\hline
\end{tabular}

*According to ref. 11 (p. 56), approximately $60 \%$ of all fuel consumed by a petroleum refinery is for direct heating and $26 \%$ of all zuel is consumed in raising process steam. Only refineries Nos. 4 and 9 included fuels for direct firing in questionnaire responses, and their percentages in this colum are close to those cited in ref. 11 . Numbers in column 3 of Table 11 for the other $i$ refineries represent the percentage of electrical plus steam energy that is consumed as process steam.

Note: To convert to SI units, multiply stean flow in $1 \mathrm{~b} / \mathrm{hr}$ by $1.26 \times 10^{-4}$ to get $\mathrm{kg} / \mathrm{s}$. 
Table 12. Summary of numbers of joilers and their associated nameplate capacities $\left(10^{3} \mathrm{Ib}\right.$ of steam/hr) for nine refineries in the survey

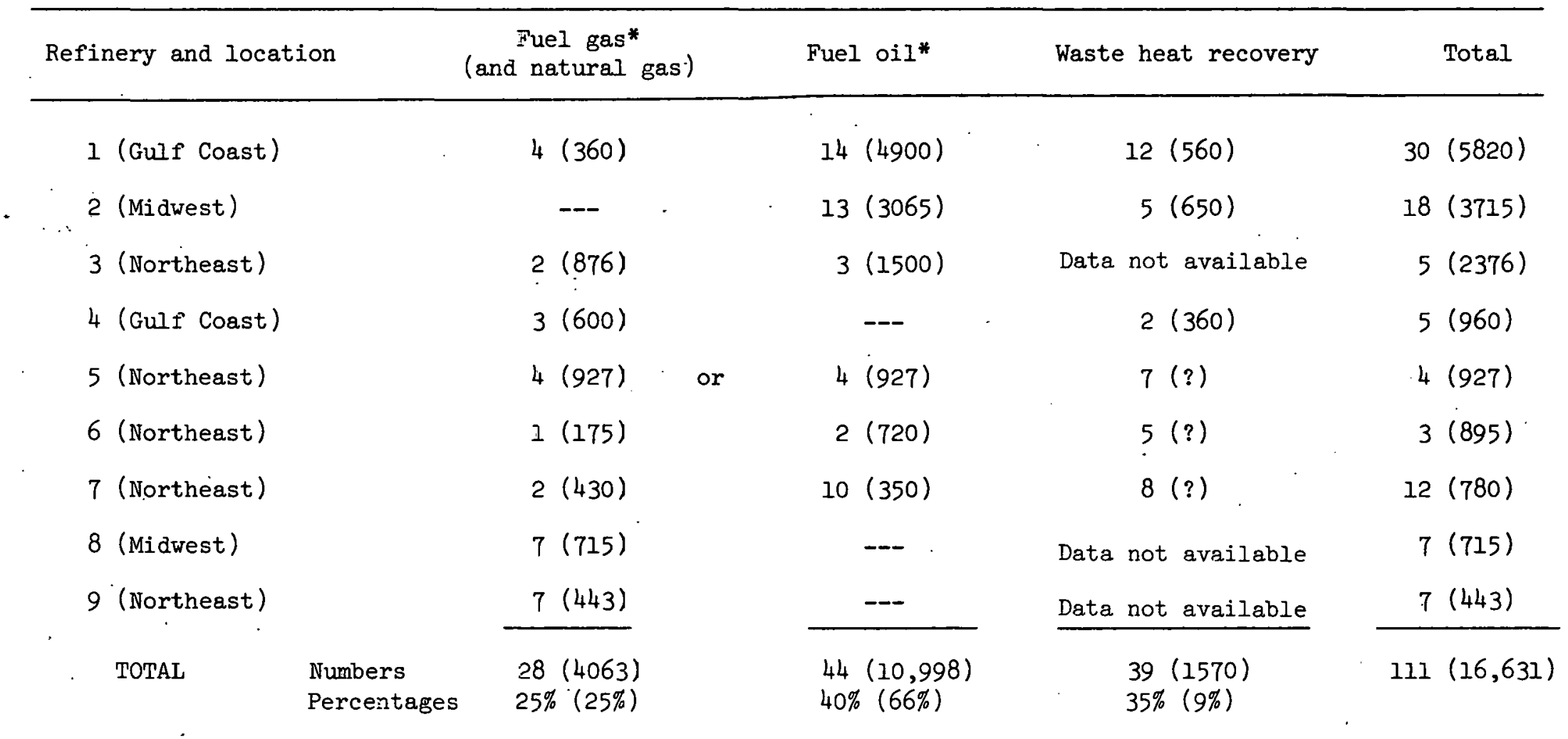

*These are by-product fuels that are utilized to fire conventional boilers.

NOTE: To convert to SI units, multiply steam flow in $1 \mathrm{~b} / \mathrm{hr}$ by $1.26 \times 10^{-4}$ to get $\mathrm{kg} / \mathrm{s}$. 
now burn fuels more plentiful than fuel gas and fuel oil, although one of the refineries plans to add two large coal-fired boilers by 1980 .

A detailed summary of boiler data for each refinery is provided in Tables 13 and 14. Boiler pressure and temperature data for refinery No. 8 were not available, so the totals in these two tables do not correspond to totals in Table 12. From Table 13 it can be seen that the majority of all boilers operate at pressures of $4137 \mathrm{kPa}(600$ psig) or less (52 out of 84 units, or 61.9\%). Furthermore, the average age of all boilers is almost 25 years, with the highest average age being associated with boilers operating under $1723.8 \mathrm{kPa}$ (250 psig).

In general, boilers at refineries are older than those at chemical plants included in this study. A large number of refinery boilers are candidates for replacement/retirement as petroleum companies attempt to improve fuel consumption efficiencies and reduce unit operating costs. In fact, one of the six major recommendations of the Energy Policy Project of the Ford Foundation, regarding refinery. fuel savings, was to "improve efficiency of steam boilers and reduce steam losses in standby equipment." 11 At refineries in the survey, this statement appears to be particularly appropriate because 37 of the 84 boilers (44\%) are older than 20 years and $26(30 \%)$ are older than 30 years. It is interesting to observe that almost all of the newer and larger boilers (nameplate capacies over $31.5 \mathrm{~kg} / \mathrm{s}$, or $250,000 \mathrm{lb}$ of steam $/ \mathrm{hr}$ ) are not yet 20 years old.

From Table 14 it can be seen that 42 of the 84 boilers (50\%) generate steam in excess of $371^{\circ} \mathrm{C}\left(700^{\circ} \mathrm{F}\right)$, and 63 boilers $(75 \%)$ produce steam at temperatures above $288^{\circ} \mathrm{C}\left(550^{\circ} \mathrm{F}\right)$. Another recommendation given in ref. 11 concerns use of high-temperature steam to generate by-product electricity in conjunction with production of process steam regardless of the electrical needs of the refinery. One of the refineries in the survey (No. 4) has an arrangement with a nearby power company in which a large fraction of its steam requirements is provided by the utility. However, no sales of by-product electricity to the utility were reported.

The applicability of light water reactors as replacements for existing steam generators at petroleum refineries appears promising for the reasons discussed on page 15. If a large fraction of steam requirements at $400^{\circ} \mathrm{F}$ and below could be met with an LWR, high-temperature steam 
Table 13. Boiler pressure breakouts for nine refineries in the survey

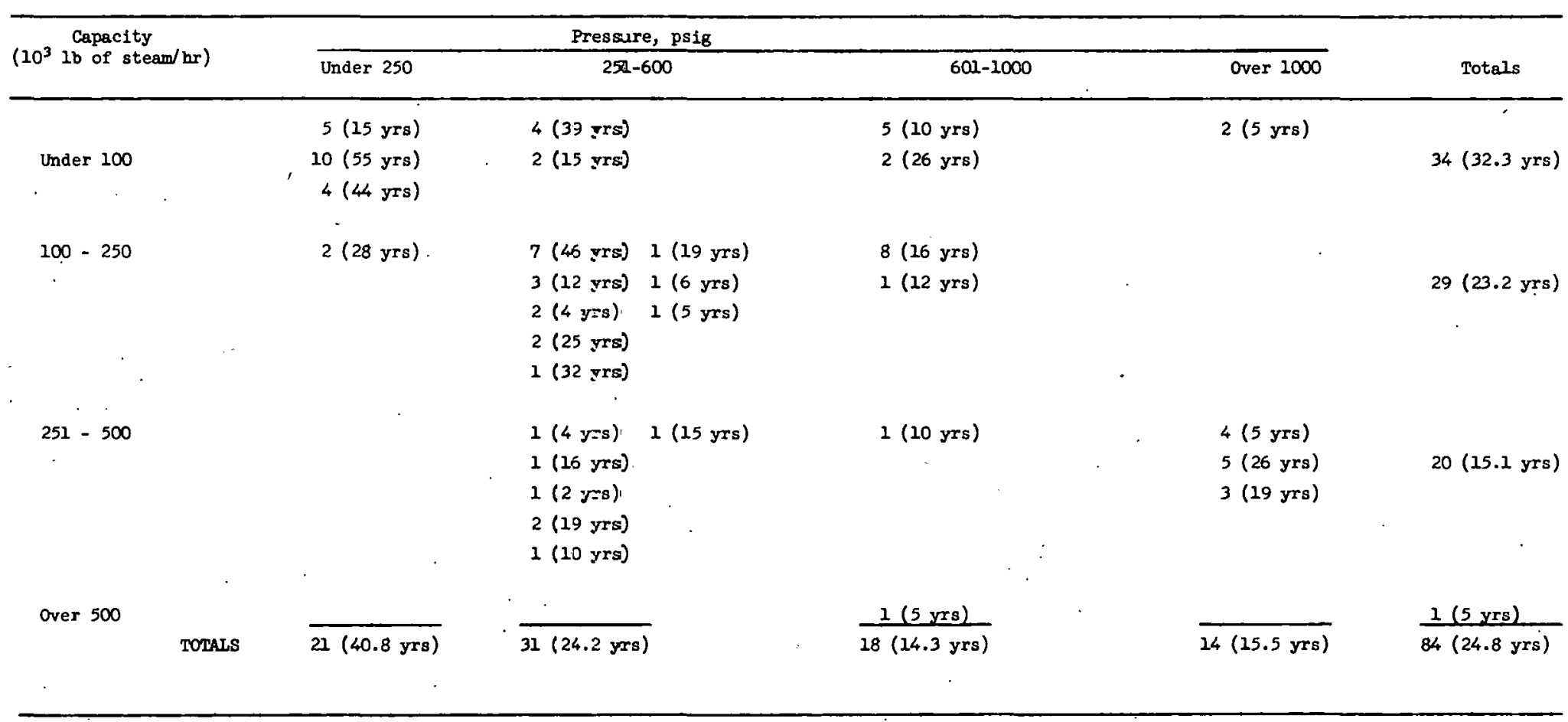

Note 1: Average age of boilers in parentheses.

Note 2: To convert to SI units, multiply steam $\mathrm{fl}$. in $1 \mathrm{~b} / \mathrm{hr}$ by $1.26 \times 10^{-4}$ to get $\mathrm{kg} / \mathrm{s}$ and multiply pressure in $1 \mathrm{~b} / \mathrm{in} .^{2}$ by 5.895 to get $\mathrm{kPa}$. 
Table 14. Boiler temperature breakouts for nine refineries in the survey

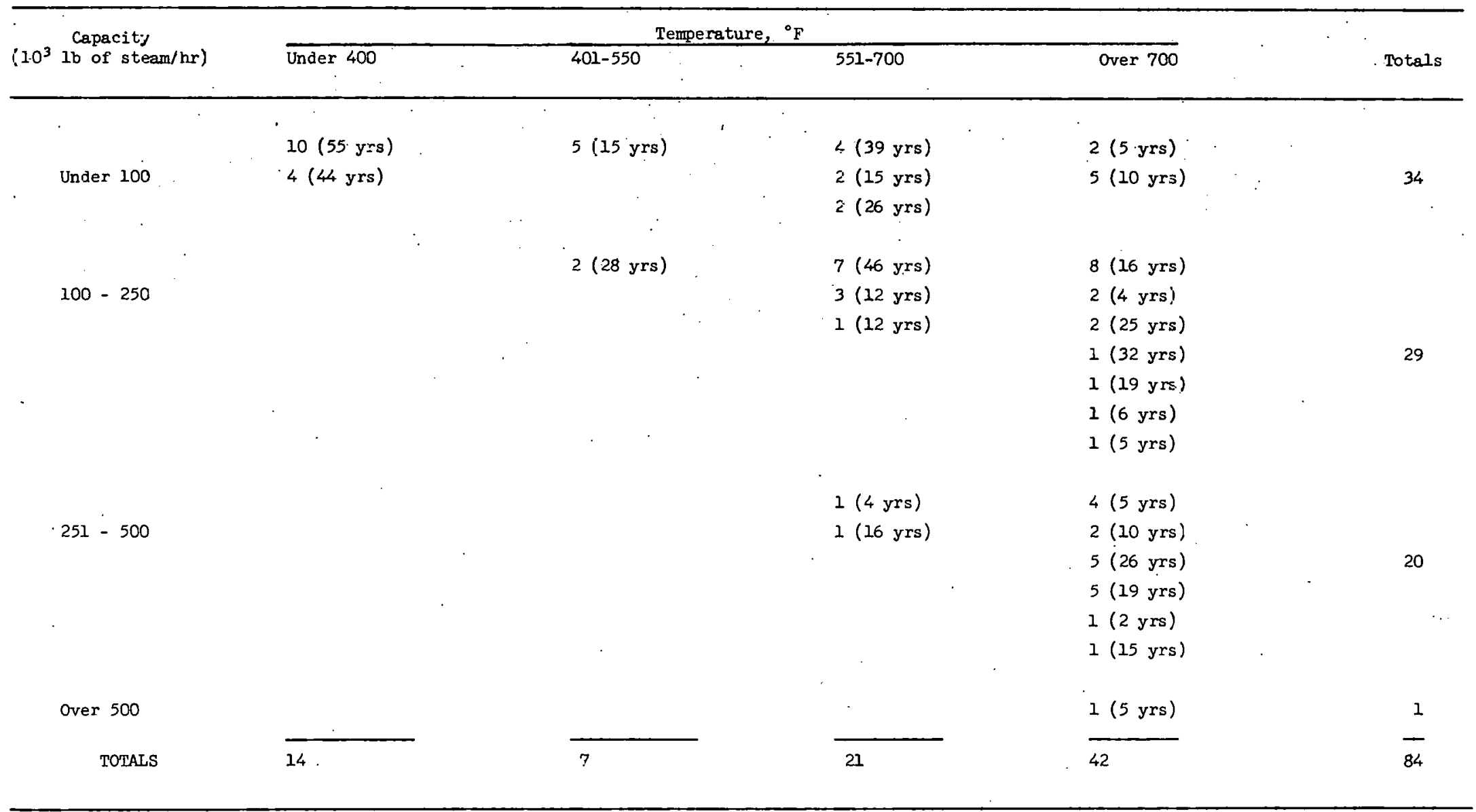

Note 1: Arerage age of bollers in parentheses.

Note 2: To eonvert to SI units, multiply steam flow in $1 \mathrm{~b} / \mathrm{hr}$ by $1.26 \times 10^{-4}$ to $\mathrm{g}^{\text {et }} \mathrm{kg} / \mathrm{s}$ and determine temperature in degrees Celsius as fol:ows, $t_{c}^{\circ}=\left(t_{F}^{\circ}-32\right) \div 1.8$. 
requirements could perhaps be satisfied with fossil or by-product fueled superheat boilers.

Turning now to reliability considerations, much information was obtained from questionnaire responses regarding the reliability of steamsupply systems at the nine refineries. The definition of reliability given on page 2 was utilized to quantify ( 1 ) average safety margins as a percent of average steam usage, (2) safety margins as a percent of the largest on-line boiler, (3) percent of clock time that desired throughput was curtailed because of equipment-related outages (unplanned) of the steamsupply system, and (4) percent of clock time that desired throughput wás reduced due to nonequipment related outages of the steam-supply system.

Results of analyzing data in Sections 1 and 2 of the questionnaire are given in Table 15. Safety margins at each refinery were found by subtracting line D of Table 15 from line B. It would have been better to have used scheduled (desired) steam demand in determining the safety margin, but none of the refinery respondents distinguished between actual steam consumption versus forecasted, or desired, steam consumption on the questionnaire.

Two interesting characteristics of the safety margin are computed in lines $\mathrm{H}$ and $\mathrm{J}$ of Table 15. Average margins (line $\mathrm{H}$ ) ranged from $3.8 \%$ of steam consumption to $60.8 \%$, with an average of around $29 \%$. Expiessed as a percent of the largest on-line boiler, safety. margins ranged from 19.0 to $200 \%$ (line J). From line $J$ it is seen that four of the nine refineries had safety margins that were $100 \%$ or better of the largest boiler. However, there is a large amount of excess capacity at all refineries because in most cases the largest unit on-line has a nameplate capacity of at least $31.5 \mathrm{~kg} / \mathrm{s}$, or $250,000 \mathrm{lb}$ of steam $/ \mathrm{hr}$ (seven of the nine refineries).

The "unreliabilities" of steam supply systems are calculated in lines $\mathrm{K}, \mathrm{L}$, and $\mathrm{N}$ of Table 15 . The overall reliability of refinery steam-supply systems (100 minus the unreliability in line $N$ ) ranges from 100 to 69.9\%, with an average value of $92.1 \%$ for all nine refineries.

From line $N$ of Table 15, it can be seen that five refineries had steam-supply systems that were unreliable $5 \%$ or less of all clock time, and the other four refineries were unreliable $5 \%$ or more of the time. There appears to be little connection (i.e., low correlation) between 
Table 15. Process steam syster capacity, consumption rate and
reilability for petroleur refineries in the survey

\begin{tabular}{|c|c|c|c|c|c|c|c|c|c|c|}
\hline & & & & & & Refine & & & & \\
\hline & Item of data & 1 & 2 & 3 & 4* & $5 * *$ & 6 & 7 & 8 & 9 \\
\hline t.. & $\begin{array}{l}\text { Average ingtalled capscity } \\
10^{9} \text { lbs of ateam per } \mathrm{hr}\end{array}$ & 5820 & 3715 & 2376 & 1120 & 1427 & 2145. & 1130 & 715 & 509 \\
\hline B. & $\begin{array}{l}\text { Average on-11ne capacity, } \\
10^{3} \text { lbs steam per } \mathrm{hr}\end{array}$ & 5450 & 3500 & 2250 & 2050 & 1250 & 1071 & 1070 & 646 & 500 \\
\hline e. & $\begin{array}{l}\text { Average on-1ine capacity, } \\
\text { as percentage of } \mathrm{A}\end{array}$ & 93.6 & 54.2 & 94.7 & 92.1 & 87.6 & 93.5 & 94.7 & 90.4 & 98.2 \\
\hline Ii. & $\begin{array}{l}\text { Average actual ateam usage, } \\
10^{3} \mathrm{lbs} \text { of steam per } \mathrm{hr}\end{array}$ & 4375 & 2800 & 1870 & 1012 & 1100 & 780 & 749 & 496 & 341 \\
\hline E. & $\begin{array}{l}\text { Average schedoled steam } \\
\text { usage, } 10^{3} \text { ibs per hr }\end{array}$ & 4375 & 2800 & 1870 & 1012 & 1100 & 780 & 749 & 49 & 311 \\
\hline F. & $\begin{array}{l}\text { Average actuai steam usage, } \\
\text { as percentage of B }\end{array}$ & 80.3 & $80.0^{\circ}$ & 83.1 & 96.4 & B8.0 & 72.8 & 70.0 & 76.8 & 62.2 \\
\hline G. & $\begin{array}{l}\text { Average safety. margin, } \\
\text { Item B-Item D }\end{array}$ & $107:$ & 700 & 380 & 38 & 150 & 291 & 321 & 150 & 189 \\
\hline H. & $\begin{array}{l}\text { Average safety margin } \\
\text { as percentage of } D\end{array}$ & $24 . E$ & 25.0 & 20.3 & 3.8 & 13.6 & 37.3 & 42.9 & 30.2 & 60.8 \\
\hline I. & $\begin{array}{l}\text { Largest unit on-line } \\
\text { (1) } 10^{3} \mathrm{lb} \text { of steam per } \mathrm{hr} \\
\text { (ii) avg. percentage of } \mathrm{B}\end{array}$ & $\begin{array}{l}550 \\
10.1\end{array}$ & $\begin{array}{l}350 \\
10.0\end{array}$ & $\begin{array}{l}500 \\
22.2\end{array}$ & $\begin{array}{l}200 \\
19.1\end{array}$ & $\begin{array}{l}287 \\
23.0\end{array}$ & $\begin{array}{l}470 \\
43.9\end{array}$ & $\begin{array}{l}283 \\
26.2\end{array}$ & $\begin{array}{l}440 \\
68.1\end{array}$ & $\begin{array}{l}135 \\
27.0\end{array}$ \\
\hline J. & $\begin{array}{l}\text { Safety margin as percentage } \\
\text { of largest unit on-line(I) }\end{array}$ & 195.5 & 200.0 & 76.0 & 19.0 & 52.3 & 61.9 & 114.6 & 34.1 & 140.0 \\
\hline$\kappa$ & $\begin{array}{l}\text { Percent of time steam supply } \\
\text { system unable to meet sched- } \\
\text { uled requirements (E) due to } \\
\text { random equipment outages }\end{array}$ & 5.8 & 0.8 & 8.3 & 0 & 30.1 & 17.3 & 3.8 & 1.4 & 0 \\
\hline L. & $\begin{array}{l}\text { Percent of time scheduled } \\
\text { steam production (E) was } \\
\text { curtailed due to non-equip- } \\
\text { ment related cutages }\end{array}$ & 0 & 0 & 0.8 & 1.9 & 0 & 0.3 & 0.3 & 0. & 0 \\
\hline M. & $\begin{array}{l}\text { Percent of time refinery } \\
\text { was completely shut down } \\
\text { for scheduled vacation or } \\
\text { plant turnaround }\end{array}$ & 0 & 0 & 0 & 0 & 0 & 0 & 0 & 0 & 0 \\
\hline s. & $\begin{array}{l}\text { Total percent of time sched- } \\
\text { wed steam production was } \\
\text { curtalled (Item K + Item L) }\end{array}$ & 5.8 & 0.8 & 9.1 & 1.9 & $\$ 0.1$ & 17.6 & 4.1 & 1.4 & 0 \\
\hline
\end{tabular}

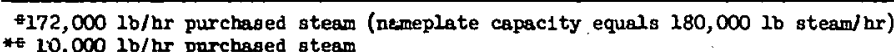

Sote: To convert to SI units, mul=1ply steam flow in $1 \mathrm{~b} / \mathrm{hr}$ by $1.26 \times 10^{-4}$ to get $\mathrm{kg} / \mathrm{s}$. 
large unreliabilities and low safety margins (lines $N$ and $J$ ). It is suspected that the high age of standby boilers tends to obfuscate the notion that high safety margins lead to low unreliabilities. In general, the larger and newer refineries tend to have more reliable steam-supply systems. It can also be observed in line $K$ that unscheduled boiler failures accounted for the majority of all curtailments in refinery throughput. Finally, to highlight information from Table 15 relevant to steamsupply system unreliability, a summary of this aspect of the survey is provided in Table 16.

Reasons for outages of any type are listed in Table 17. Here the magnitude of the loss and its approximate duration are indicated. Also the severity of outages, as an average, is shown for each refinery, where 0 represents total refinery shutdown given that there was an outage and 1 represents the ideal condition of no production curtailments due to equipment outages during the year survey (1973 to 1974).

Results of this study of steam-supply systems at petroleum refineries indicate that sources of steam ought to be at least $92 \%$ reliable based on an arithmetic average of individual reliabilities. Because there were two major groupings of refinery steam-supply system reliabilities (greater than $98 \%$ and less than 98\%), another more representative figure such as the median reliability should be considered. The median is the point that divides responses into two halves, so the median unreliability here would be about $4.0 \%$. That is, there are four unreliabilities smaller than $4 \%$ and four that are larger. Based on the median, steam-supply systems are about $96 \%$ reliable.

\section{STUDY RESULTS FOR PRIMARY METALS INDUSTRIES}

Only three responses to the questionnaire were received from companies in this industry. Two were from aluminum companies and one was from a steel company. The total rate of energy consumption for the three companies was $91.40 \times 10^{12} \mathrm{~kJ} /$ year $\left(86.63 \times 10^{12} \mathrm{Btu} / \mathrm{year}\right)$ which is roughly equivalent to $1246.1 \mathrm{~kg} / \mathrm{s}\left(9.89 \times 10^{6} \mathrm{lb}\right.$ steam $\left./ \mathrm{hr}\right)$. According to ref. 5, the total energy in fuels used by primary metals industries in 1971 was $3661 \times 10^{12} \mathrm{~kJ}$ ( 3470 $\left.x 10^{12} \mathrm{Btu}\right)$. Thus the three companies in the survey comprised roughly $2.5 \%$ of total energy consumed in the primary metals industry. 
Table 16. Summary of reliability measures for nine refineries in the survey

\begin{tabular}{|c|c|c|c|c|c|c|c|c|c|c|c|}
\hline & \multirow{2}{*}{ Reliatility measure } & \multicolumn{9}{|c|}{ Refinery } & \multirow{2}{*}{$\begin{array}{l}\text { Averages for } \\
9 \text { refineries }\end{array}$} \\
\hline & & 1 & 2 & 3 & 4 & 5 & 6 & 7 & 8 & 9 & \\
\hline & & & & & & & & & & & . \\
\hline Line $K$ & $\begin{array}{l}\text { Percent of time steam-supply } \\
\text { system unable to meet scheduled } \\
\text { prodiction due to random equip- } \\
\text { ment failures }\end{array}$ & 5.8 & 0.8 & 8.3 & 0 & 30.1 & 17.3 & 3.8 & 1.4 & 0 & $7.50 \%$ \\
\hline Lin $€ \mathrm{~L}$ & $\begin{array}{l}\text { Percent of time steam-supply } \\
\text { system unajle to meet scheduled } \\
\text { production due to noneguipment } \\
\text { related oujages (planned and } \\
\text { unplanned) not including vacation }\end{array}$ & 0 & 0 & 0.8 & 1.9 & 0 & 0.3 & 0.3 & 0 & 0 & $0.37 \%$ \\
\hline Line $N$ & $\begin{array}{l}\text { Total time (percent) steam-supply } \\
\text { system unable to meet scheduled } \\
\text { production }\end{array}$ & 5.8 & 0.8 & 9.1 & 1.9 & 30.1 & 17.6 & 4.1 & 1.4 & 0 & $7.87 \%$ \\
\hline Line $\mathrm{G}$ & $\begin{array}{l}\text { Average safety margin }\left(10^{3} \mathrm{lb}\right. \\
\text { stear } / \mathrm{hr} \text { )--average on-line ca- } \\
\text { pacity minus average steam demand }\end{array}$ & 1075 & 700 & 380 & 38 & 30 & 81 & 26 & 150 & 189 & $296.6 \times 10^{3}$ \\
\hline Line $\mathrm{J}$ & $\begin{array}{l}\text { Average safety margin as percent } \\
\text { of largest boiler on-line }\end{array}$ & 195.5 & 200.0 & 76.0 & 19.0 & 10.5 & 17.2 & 9.3 & 34.1 & 140.0 & $78 \%$ \\
\hline
\end{tabular}


Table 17. Number and severity of outages represented by lines $K, L$, and $M$ of Table 15

\begin{tabular}{|c|c|c|}
\hline Refinery & $\begin{array}{l}\text { Magnitude of capacity } \\
\text { loss (lb steam } / \mathrm{hr} \text { ) and } \\
\text { duration of the loss }\end{array}$ & $\begin{array}{l}\text { Severity of outage, } \\
\text { (Available capacity on- } \\
\text { line during the outage } \\
\quad \div \text { line E) }\end{array}$ \\
\hline 1 & $\begin{array}{l}\text { Loss of approximately } 17 \% \text { of total name- } \\
\text { plate capacity for } 3 \text { weeks. The boiler } \\
\text { outage ( } 3 \text { weeks) was a random outage. }\end{array}$ & $\cdot-0.99$ \\
\hline 2 & $\begin{array}{l}\text { Random boiler malfunctions resulted in } \\
\text { loss of around } 20 \% \text { of total nameplate } \\
\text { capacity for } 3 \text { l-day outages per year } \\
\text { (average) }\end{array}$ & $\sim 0.99$ \\
\hline 3 & $\begin{array}{l}\text { Loss of } 33 \% \text { of nameplate capacity for } \\
1 \text { month (scheduled boiler outage). A fire } \\
\text { caused a total shutdown for } 3 \text { days. }\end{array}$ & $\sim 0.80$ \\
\hline 4 & $\begin{array}{l}\text { Total shutdown for } 2 \text { days because of storm, } \\
\text { random boiler malfunctions caused a loss of } \\
\text { roughly } 1 / 3 \text { of rated capacity for } 5 \text { days } \\
\text { (average) }\end{array}$ & $\sim 0.75$ \\
\hline 5 & $\begin{array}{l}\text { Forced boiler outages }(3) \text { caused } 1 / 3 \text { loss } \\
\text { in total capacity for } 110 \text { days }\end{array}$ & $\sim 0.70$ \\
\hline 6 & $\begin{array}{l}\text { Forced boiler outages ( } 2 \text { ) caused loss of } \\
\text { about } 50 \% \text { of total capacity for } 10 \text { days } \\
\text { equivalent }\end{array}$ & $\sim 0.75$ \\
\hline 7 & $\begin{array}{l}\text { Forced boiler outages ( } 5) \text { resulted in loss } \\
\text { of } 40 \% \text { of total capacicy for } 13 \text { days } \\
\text { duration }\end{array}$ & $\sim 0.65$ \\
\hline 8 & $\begin{array}{l}\text { Two separate random boiler outages each } \\
\text { resulted in a } 33 \% \text { loss of total capacity } \\
\text { for } 5 \text { days (total) during the year }\end{array}$ & $\sim 0.90$ \\
\hline 9 & $\begin{array}{l}\text { One scheduled outage reported, no curtail- } \\
\text { ment of scheduled production }\end{array}$ & 1.00 \\
\hline
\end{tabular}


Table 18 shows the breakout of total energy for production of steam. It is apparent that only a small fraction of total energy in these companies is consumed for purposes of generating steam. Two of the companies used a large amount of the steam that they did produce for process heat applications. The steel company required no steam for such uses but did use 50\% of its steam for mechanical drivers.

Data included in Table 19 indicate that average boiler ages are fairly high and that most of the steam-generating capacity (about $74 \%$ ) was rated in the 288 to $371^{\circ} \mathrm{C}\left(550\right.$ to $\left.700^{\circ} \mathrm{F}\right)$ range. This tends to confirm the fact that process steam temperatures in primary metals companies are generally too high for light-water reactors (BWRs or PWRs) to produce. It is likely that high-temperature gas-cooled reactors and/or fossil-fueled steam generators could satisfy future process energy needs of a consortium of primary metal companies. However, lower temperature steam could be utilized by mechanical drivers with a corresponding loss in thermal efficiency.

Additional information regarding the production and consumption of steam at the three companies is provided in Table 20. Here it is observed that all steam-supply systems were 100\% reliable during the survey period. This reflects conditions under which primary metals companies operate: they are not heavily dependent on steam to maintain their processes, and they cannot tolerate shutdowns or significant losses of electrical power.

With a sample size of only $2.5 \%$ (based on total energy consumed, not steam energy consumed) and three plants responding in the primary metals industry, it is felt that general conclusions about industry-wide steam consumption patterns and steam-supply system reliabilities would be inappropriate. 
Table 18. Energy procuction and consumption data for three primary metals plants in the survey (Most data for the period July 1, 1973 to June 30, 1974)

\begin{tabular}{|c|c|c|c|c|c|}
\hline Plant & $\begin{array}{l}\text { Total energy consumption } \\
\text { rate (electrical, steam and } \\
\text { other) in equivalent } \\
\text { steam flow, lb/hr }\end{array}$ & $\begin{array}{l}\text { Total steam } \\
\text { production } \\
\text { rate, lb/hr }\end{array}$ & $\begin{array}{l}\text { Steam energy con- } \\
\text { sumption as a } \\
\text { percent of total } \\
\text { energy consumption }\end{array}$ & $\begin{array}{l}\text { Steam energy } \\
\text { generated at } \\
\text { central plant as } \\
\text { percent of total } \\
\text { steam energy }\end{array}$ & $\begin{array}{l}\text { Steam energy } \\
\text { for direct pro- } \\
\text { cess heat as } \\
\text { percent of to- } \\
\text { tal steam energy }\end{array}$ \\
\hline 1 & $\begin{array}{c}6.901 \times 10^{6}(77,000 \mathrm{~kW} \text { piurchased, } \\
0 \mathrm{~kW} \text { self-gererated })\end{array}$ & $8.7 \times 10^{5}$ & 12.6 & 87.4 & 0 \\
\hline 2 & $\begin{array}{l}1.574 \times 10^{6} \text { (278,188 kW purchased, } \\
153,307 \mathrm{~kW} \text { self-gener.ated by } \\
\text { hydroelectric generators) }\end{array}$ & $9.76 \times 10^{4}$ & 6.2 & 100.0 & 89.4 \\
\hline \multirow[t]{2}{*}{3} & 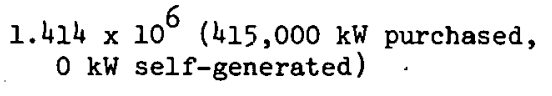 & $3.4 \times 10^{3}$ & 0.2 & 100.0 & 100.0 \\
\hline & . & . & - & & \\
\hline
\end{tabular}

Note: To convert to SI units, multiply steam flow in $1 \mathrm{~b} / \mathrm{hr}$ by $1.26 \times 10^{-4}$ to get $\mathrm{kg} / \mathrm{s}$. 
Table 19. Boiler temperature breakouts for three primary metals plants in the survey

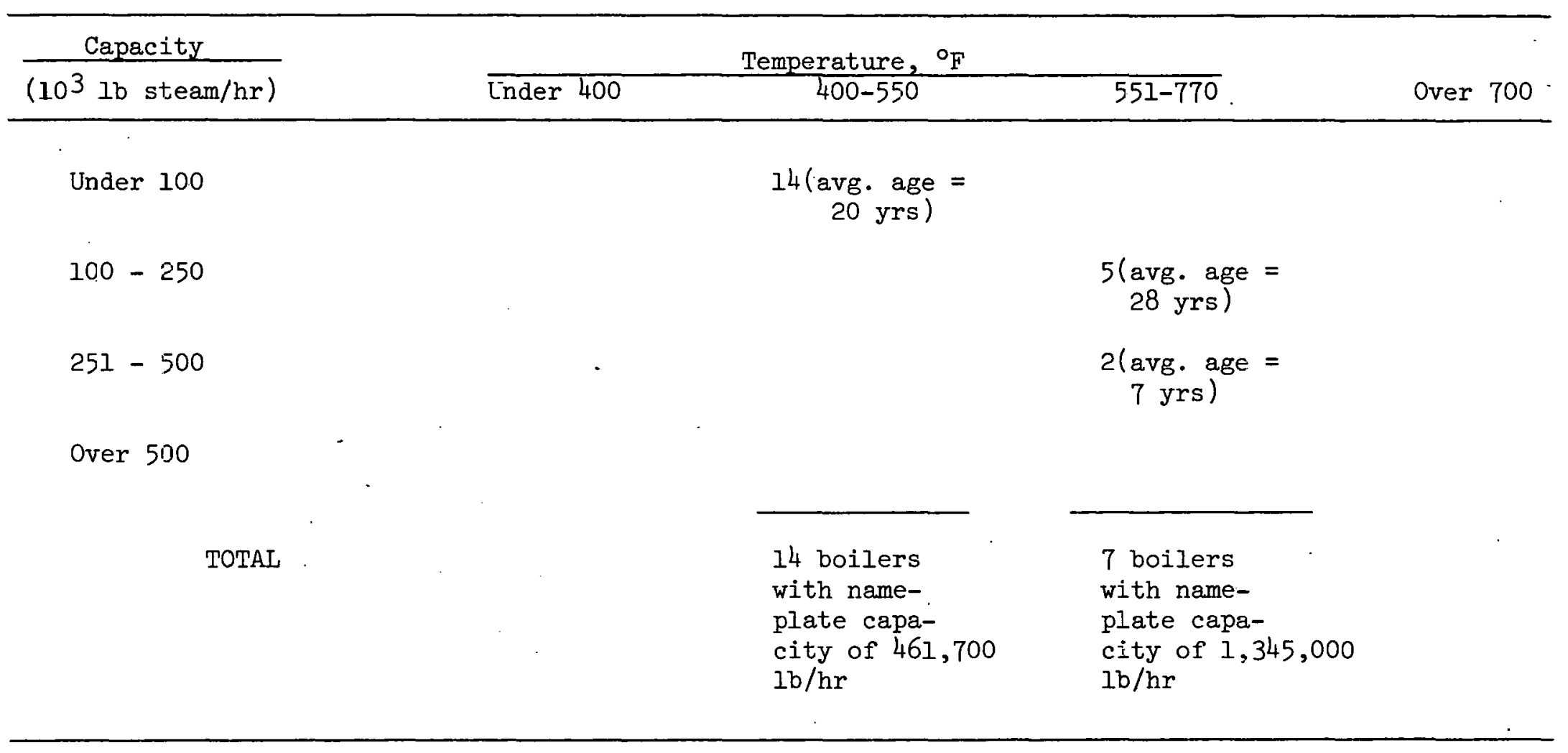

Note: To convert to SI units, multiply steam flow in $1 \mathrm{~b} / \mathrm{hr}$ by $1.26 \times 10^{-4}$ to get $\mathrm{kg} / \mathrm{s}$ and determine temperature in degrees Celsius as follows, $t_{C}^{\circ}=\left(t_{F}^{\circ}-32\right) \div 1.8$. 
Table 20. Process steam system capacity, consumption rate and reliability for primary metal companies in the survey

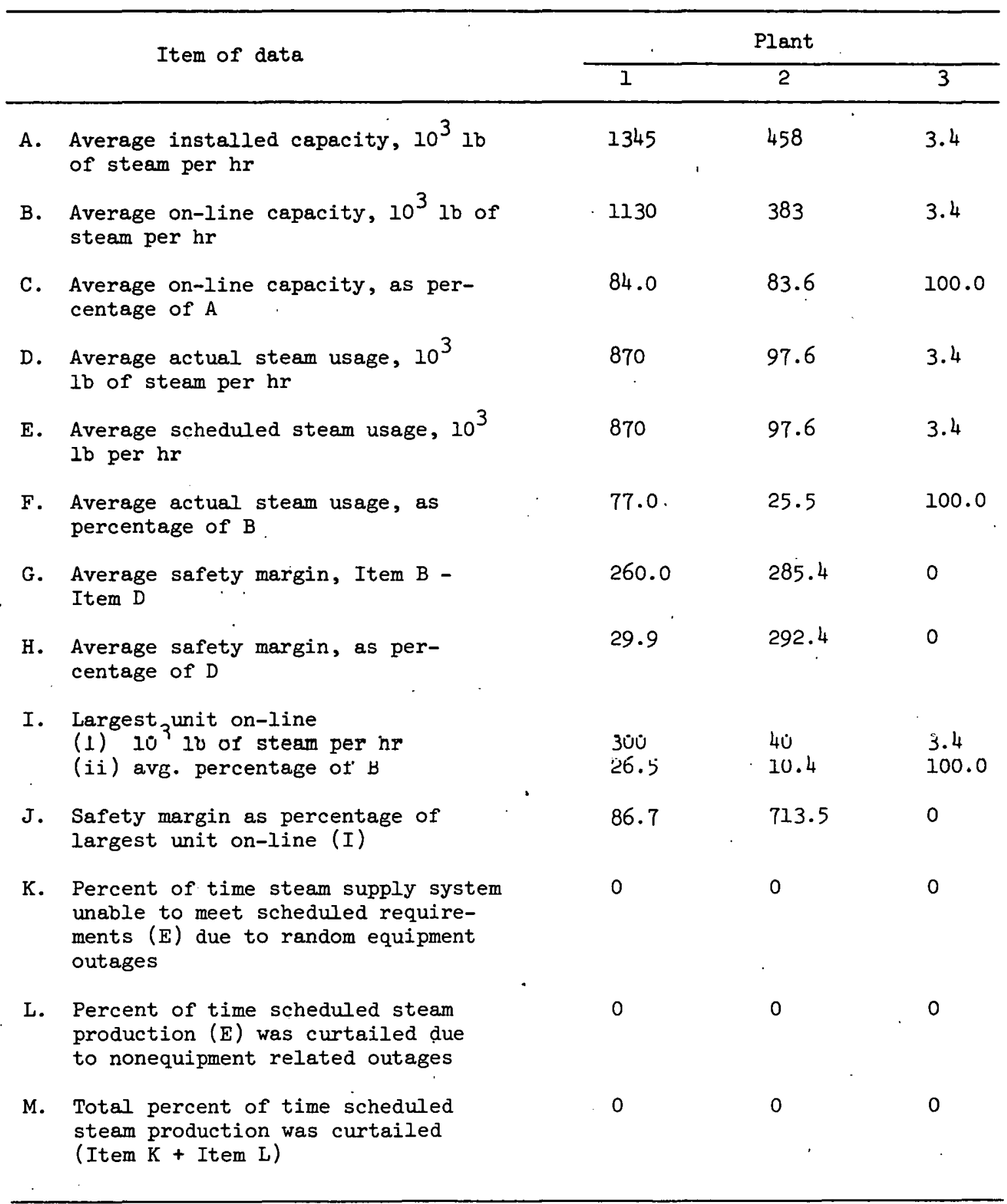


CONCLUSIONS OF THE STUDY

In studies of alternative industrial process energy systems that may be feasible in the near future, the question is often raised about how reliable the energy source must be to satisfy industry's requirements. This study was initiated to gather information from three industries regarding process energy system reliabilities that were actually experienced during 1973 to 1974. Some basis for distinguishing between what companies stated that they would like to have concerning their "economic target levels" versus what they experienced during the survey period could then be established. It is believed the estimated reliability of the steam-supply system at companies studied represents a parameter in their operation that is at least minimally acceptable to them. * Thus results reported in previous sections should be viewed as "what actually happened" rather than "what should have happened" under ideal economic conditions. Furthermore, these results were obtained from some of the largest plants within the industries studied.

Based on process steam-system reliabilities obtained from data reported in the questionnaire, it is concluded that sources of process steam in the chemical industry are presently $98 \%$ reliable. That is, they are capable of meeting or exceeding forecasted steam production requirements on a continuous basis except. for 7 days per year on the average. Individual plant reliabilities ranged from 100 to $89 \%$, so there is considerable variation about the average reliability of $98 \%$. These relatively high reliabilities were attained by excess on-IIne capacity. In fact, 11 of the 17 plants had excess capacity that was at least $80 \%$ of their largest boiler. From Table 9 (lines $L$ and $N$ ) it can be concluded that about $30 \%$ of all steam curtailments resulted from nonequipment related outages.

Concerning the nine petroleum refineries in the survey, their average reliability was roughly $92 \%$. This corresponds to 29 days of the year that

*

Because the year studied (1973 to 1974) was only a "snapshot" of long-term performance, representatives of some companies stated that this particular year provided a highly favorable picture of their operations. Others commented that the 1973 to 1974 period was the worst year in their history relative to unscheduled equipment outages, vinlent storms, etc. 
scheduled production at an average refinery had to be curtailed because of random boiler outages, operator errors, violent storms, etc. A very large fraction (roughly 95\%) of steam production curtailments were due to equipment related outages. Perhaps this can be partially. explained by recalling that the average age of refinery boilers was almost 25 years.

Probably a more representative estimate of actual reliability is given by the modal response which was $96 \%$. This figure divides responses into two groups such that one group of refineries experienced reliabilities higher than $96 \%$ and the other group had reliabilities lower than $96 \%$. Because the nine refineries in this study accounted for better than $10 \%$ of all steam produced at refineries in 1973 to 1974 , it is believed that a $96 \%$ reliable steam supply system is quite reasonable as a representative industrywide operating parameter.

Finally, reliabilities of process energy systems in the primary metals industry were found to be 100\%. This means for the period 1973 to 1974 there were no interruptions in process energy that resulted in the curtailment of scheduled production. The sample size was small, and thus general conclusions appear to be inappropriate.

As a follow-on to this study, various combinations of nuclear steam systems and nuclear-fossil steam systems will be investigated that are capable of meeting or exceeding reliability levels required for applications in candidate industries. To accomplish this, three fundamental considerations must be taken into account: (1) the total amount of steam required under normal and maximum operating conditions by individual companies and/or industrial parks, (2) the cost and overall availabilities of alternative configurations of nuclear and fossil units that would satisfy stated industrial energy reliability requirements, and (3) the forced outage characteristics and load-shedding qualities of the nuclear steam-supply systems being evaluated (i.e., abruptness of load loss, time available to bring a backup unit on-line, and time needed to bring standby units into operation).

A basic input to the dctermination of optimum nuclear and/or fossil steam supply systems is information concerning continuity of the energy 
supply from steam generators being considered for process heat applications. In the follow-on study, a principal concern will center on quantification of steam availability from nuclear steam generators in amounts necessary to satisfy industrial reliability requirements.

\section{REFERENCES}

1. Stanford Research Institute, Pattern of Energy Consumption in the United States, November 1971, prepared for the Office of Science and Technology.

2. T. D. Anderson et al., An Assessment of Industrial Energy Options Based on Coal and Nuclear Systems, ORNL-4995, Oak Ridge National Laboratory, July 1975, p. 1 .

3. Ibid., p. 19.

4. Ibid., p. 20 .

5. Evaluation of New Energy Sources for Process Heat, Final Report of N.S.F. Grant No. OEP74-18055, Prepared by the Dow Chemical Company, September 1975, p. 39.

6. Op. cit., Stanford Research Institute.

7. Ibid., p. 17 .

8. Report on Equipment Availability for the Ten-Year Period, 1965-1974, Edison Electric Institute Publication No. 75-50, New York, November 1975.

9. The Potential Industrial Market for Process Heat from Nuclear Reactors, prepared for the Oak Ridge National Laboratory by Dow Chemical U.S.A. under subcontract No. 4384, ORNL/TM-5497, January 1976, p. 5.

10. Energy Consumption in Manufacturing, A report to the Energy Policy Project of the Ford Foundation, Ballinger Publishing Company, Cambridge, Massachusetts, 1974, p. 47.

11. E. P. Gyftopoulos et al., Potential Fuel Effectiveness in Industry, A Report to the Energy Policy Project of the Ford Foundation, Ballinger Publishing Company, Cambridge, Massachusetts, 1974, pp. 56-57. 
THIS PAGE

WAS INTENTIONALLY

LEFT BLANK 
APPENDIX A

\section{QUESTIONNAIRE ON ENERGY REQUIREMENTS \\ FOR PROCESS ENERGY INDUSTRIES}

The purpose of this questionnaire is to obtain a representative sampling of various operating characteristics in selected energy intensive industries. Of particular importance is the collection of data concerning operations which utilize significant amounts of steam-supplied process heat. In our study "process heat" includes steam-supplied energy required for chemical reactions, drying operations, mechanical drivers, etc. Information concerning various operating parameters of the steam-supply systems being used in process energy industries is also of interest.

The questionnaire consists of two interrelated sections: (1) the formulation of a graphic display of past operating conditions, and (2) questions concerning various supplementary details about these conditions. The graphic display technique was chosen in the first section to facilitate the presentation of data in condensed form. It is realized that this format may require some rather general assumptions and numerical approximations, but please attempt to complete the form as best you can in view of your operating experience from mid1973 to mid-1974 (or other convenient survey period). 
Section 1 -- Steam-Supplied Process Heat Requirements

General Information:

Company .

Division

Location

Major Products At This Location

Respondent's Name and Position

Phone Number

A Graphical Approach to Data Collection:

In order to tàcilltate a luúe yeneral undoretanding nf what information is desired, an illustrative example is shown on the following page. This illustration is simply for demonstrative purposes and is not meant to be representative of any particular industry's conditions.

Line A - Total Installed steam Generating Capacity This is the total nameplate capacity (in thousands of pounds per hour) of all currently installed and. operable steam generating equipment operating under standard load conditions.

Line B - On-Line Steam Generating Capacity Amount shown in Line A minus that capacity which is 
currently unavailable (on less than 24-hour notice) due to breakdown, routine or preventative maintenance, or fuel usage limitations or shortages.

Line C - Theoretical Steam Level Required to Meet "MostDesirable" Production Level -

This most desirable level would be dictated by current marketing considerations and routine plant operating conditions. It is, in effect, a steam forecast based on anticipated market factors. Line $\mathrm{C}$ would be dependent upon all factors other than availability of steam supply during the survey period, i.e. raw material and labor availability, market demand, inventory levels and general business conditions.

Line D - Actual Level of Steam Used During Survey Period This line is a plot of total steam usage during the survey period from mid-1973 to mid-1974. Weekly averages are highly desirable, if available. Otherwise use monthly averages.

For the above items, the effect and duration of operating anomalies that may have occurred during the study period is of more importance than detailed characteristics of more or less standard operation. On the graph that follows, please provide the information defined as "Lines $A-D$ " on the illustrative example. If you prefer, a tabular presentation of this information would be appropriate. Any notes you care to make regarding additions to capacity, plant shutdowns, reduced plant output due to lack of process heat, etc. would be quite helpful. 


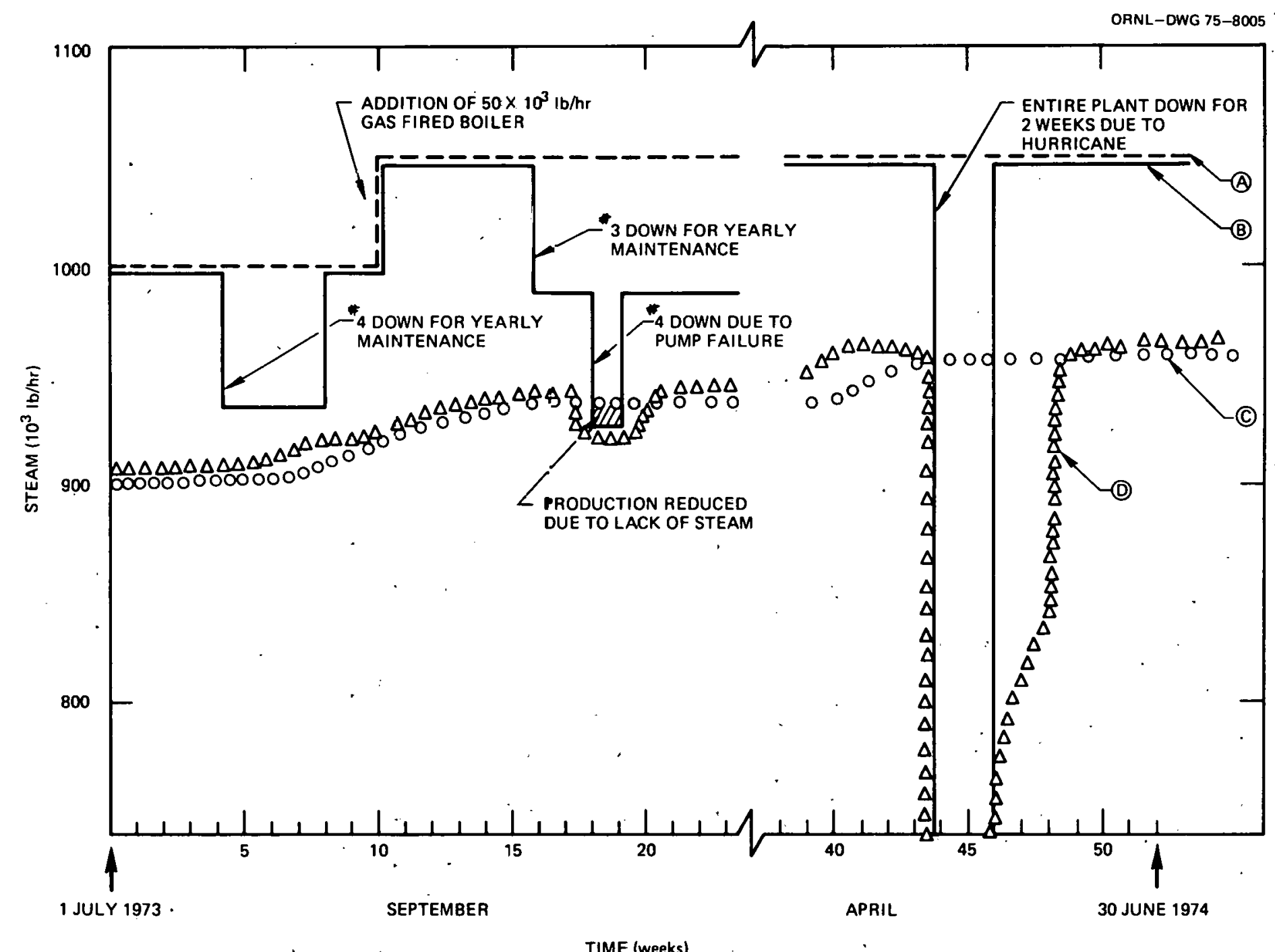




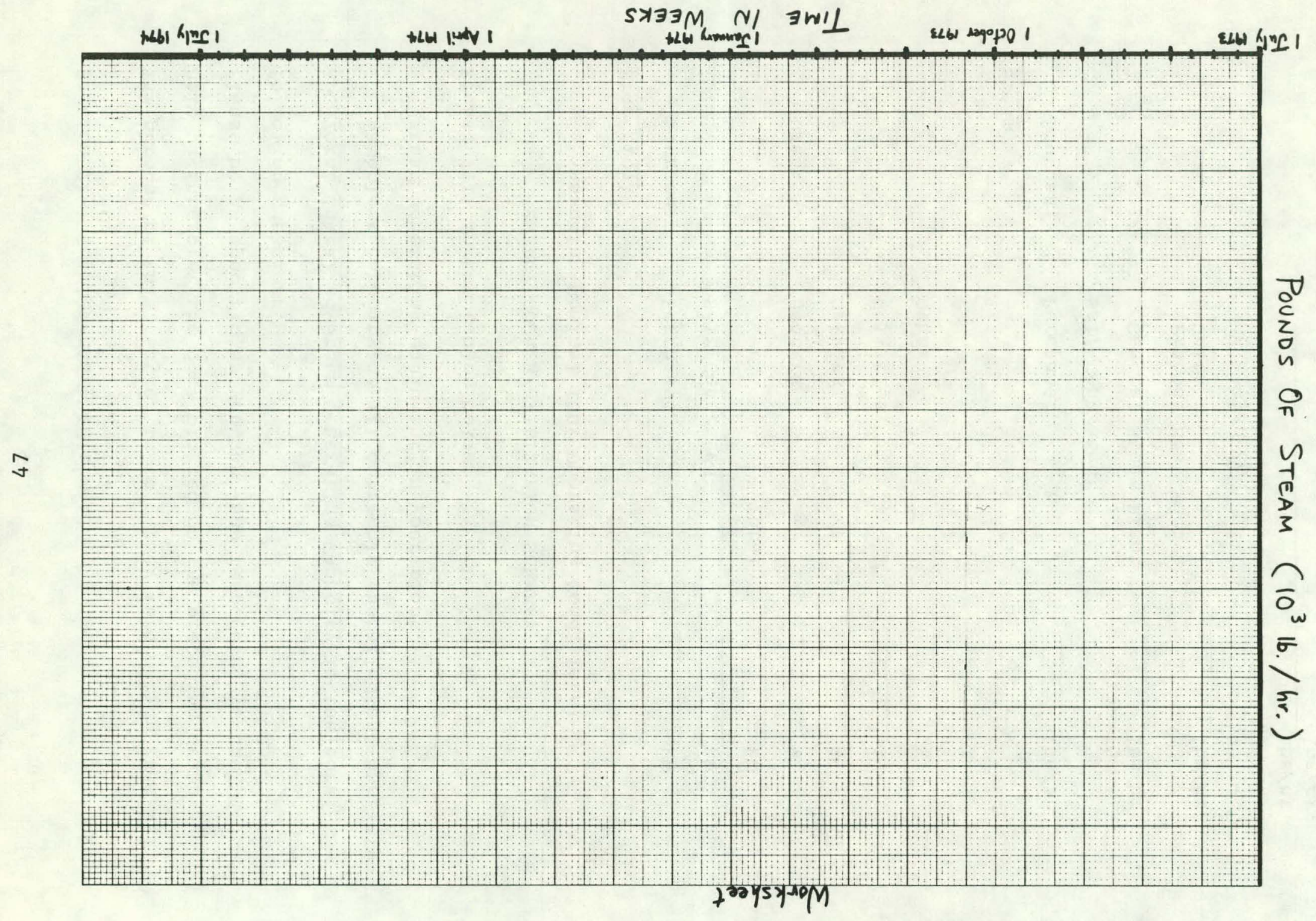


Section 2 -- Supplementary Information

The purpose of this section is to gather information that will help us interpret the data plotted on the preceding graph. Please be as specific as you can when responding to the following questions.

A. Total Installed Steam Generating Capacity is the total nameplate capacity of all currently installed and operative steam generating equipment in your plant.

Please fill in the tables below.

ENERGY SOURCE/UTILIZATION SUMMARY

(Assuming Nominal 1008 Operating Conditions)

\section{Electrical}

Sources:

Purchased $\mathrm{kW}$

Self-Generated $\mathrm{kW}$

Uses :

Heaters Total kW

Drivers 8

Utilities

other

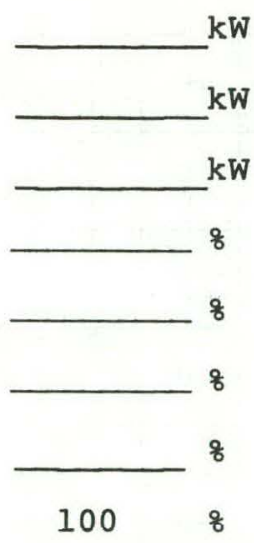

$\underline{\text { Steam }}$

Sources :

Purchased Ibs/hr.

Self-Generated:

Central Steam Plant $\mathrm{lbs} / \mathrm{hr}$. Process Heat Recovery Units lbs/hr. Other Sources lbs/hr. $1 \mathrm{bs} / \mathrm{hr}$. Total lbs/hr. 
Uses:

Power Generation

lbs/hr.

Drivers

lbs/hr.

Direct Process Heat

$\mathrm{lbs} / \mathrm{hr}$.

Other Applications

Ibs/hr.

Other Energy Sources (list sources and specify units)
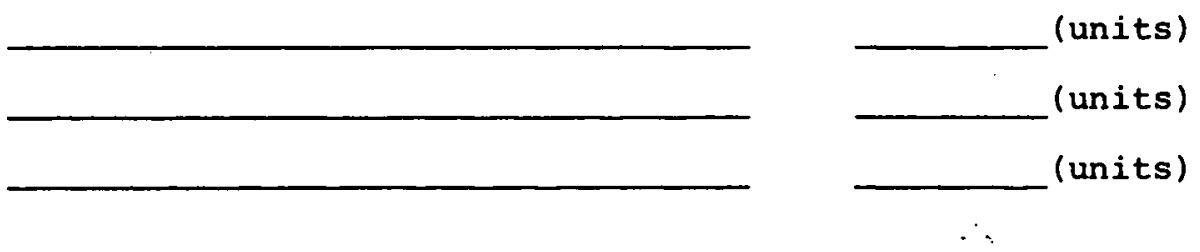

Total

SUMMARY OF STEAM GENERATING CAPABILITY

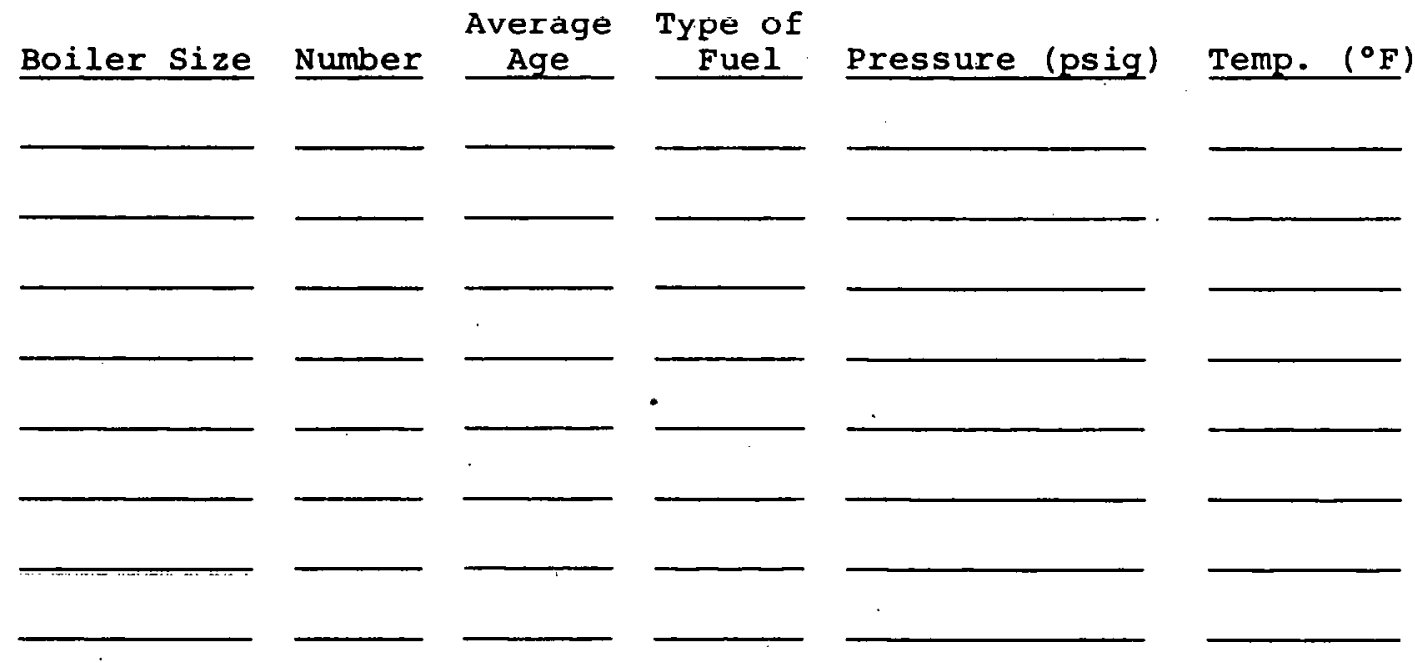

Do you anticipate replacing some of your existing units?

If yes, what are the operating characteristics of the replacement (temp., pressure, capacity)?

If yes, what type of fuel will be used?

If yes, when will the new units be on-line? 
B. On-Line Steam Generating Capacity is total installed capacity minus capacity presently unavailable (e.g. on less than a 24-hour notice) because of unscheduled interruptions, routine or preventative maintenance, fuel shortages, etc.

Please list reasons why various steam supply systems were not available at times during the 52-week period plotted earlier. 1. Unscheduled (random) outages:

2. Outages known or schedulable 48 hours in advance:

3. List duration of the outage:

What is the minimum level of steam production capacit.y requirer to keep your company's processes in an operative (marginally) condition?

C. Amount of Steam Required to Meet "Most Desirable" Production Level is determined largely by current marketing conditions and technical production decisions at your plant.

Please indicate on a $1-5$ scale the average conditions that existed at your plant during the 52-week survey period. 


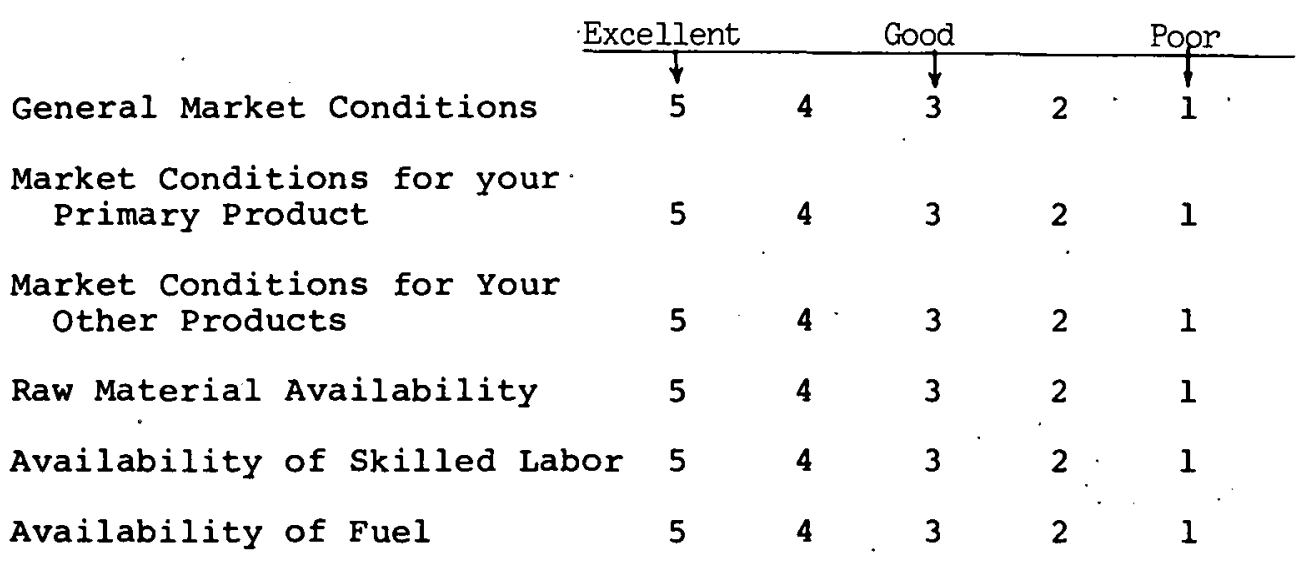

Do you think that the most desirable production level (or schedule) was limited by the amount of process heat provided by steam during the survey period? If yes, why?

\section{Actual Level of Steam Used for Process Heat is a direct result of actual production in the 52-week survey period.}

Please answer these questions with reference to your overall plant operation.

1. If the total available steam suppiy unexpectedly fell (e.g. within a period of five minutes) to a level 108 velow that required for maintaining production at the scheduled level and remained there for 4 hours, how would you classify the resulting condition? (Indicate Item Number)

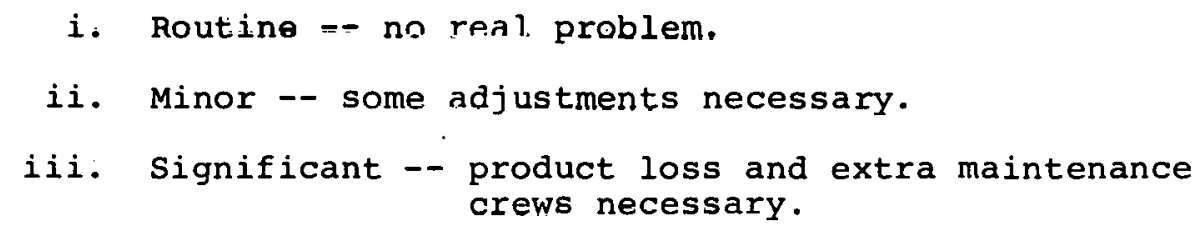


iv. Major - considerable product loss and some system rework required.

v. Catastrophic -- very costly system-wide problems exist.

2. Same as (1) except steam supply was 208 lower. Which condition would prevail?

3. Same as (1) except steam supply was 408 lower. Which condition would prevail?

4. Same as (1), except a 108 loss within a period of 4-6 hours for 48 hours. Which condition would prevail?

5. Same as (1), except a 408 loss within a period of $\underline{4-6}$ hours for 48 hours. Which condition would prevail?

6. Does your operation have a general policy of (a) plant-wide or (b) product division-wide annual general shutdown for maintenance, equipment relocation operations, vacations, or product change-overs, etc. If so, please explain the degree of shutdown, length, and frequency of occurence.

7. Has your operation been forced to completely shut down at any time in the past five ycars due to strikes, accidents, or natural occurences such as floods, earthquakes, etc.? Yes No

If your answer is yes, please give a brief explanation. 
ORNL/TM-5428

\section{INTERNAL DISTRIBUTION}

1. T. D. Anderson

2. T. E. Cole

3. W. E. Cooper

4. F. L. Culler

5. J. G. Delene

6.' G. G. Fee

7. M. J. Goglia

8. J. E. Jones

9-12. 0. H. Klepper

13. W. J. McCarthy, Jr.

14. M. Olszewski
15. H: Postma

16. M. W. Rosenthal

17. M. R. Sheldon

18. M. J. Skinner

19. I. Spiewak

20. J. J. Taylor

21. D. B. Trauger

22. W. J. Wilcox

23-24. Central Research Library

25. Document Reference Section

26-28. Laboratory Records

\section{EXTERNAL DISTRIBUTION}

29-57. Industrial Contributors

58. S. L. Adams, Gulf States Utilities, P.0. Box 2951, Beaumont, Tex. 77704

59. Seymour Alpert, Electric Power Res. Inst., 3412 Hillview Ave., Palo Alto, Calif. 94304

60. R. W. Barnes, Dow Chemical Company, 2040 Dow Center, Midland, Mich. 48640

61. D. J. Blickwede, Bethlehem Steel Corp., Bethlehem, Pa. 18016

62. R. B. Fancher, Planning and Research, Pacific Gas and Electric Company, 77 Beale Street, San Francisco, Calif. 94106

63. M. W. Golay, Dept. of Nuclear Engineering, Massachusetts Institute of Technology, 138 Albany st., Cambridge, Mass. 02139

64. Leon Green, Jr., MITRE Corp., Westgate Research Park, McLean, Va. 22101

65. Tom Gross, Office of Conservation and Environment, Federal Energy Agency, 12 Pennsylvania Ave., Washington, D. C. 20461

66. A. E. Kakretz, Manager, Gas Reactor Development, General Electric Co., Fairfield, Conn. 06430

67. A. T. McMain, General Atomic Company, P.0. Box 81608, San Diego, Calif. 92138

68. M. J. McNelly, General Electric Co., 175 Curtner Ave., Mail Stop 5/10, San Joee, Calif. 95125

69. H. G. MacPherson, Dept. of Nuclear Engineering, University of Tennessee, Knoxville, Tenn. 379.76

70. Capt. A. V. Nida, Research and Technology Division, U.S. Army Facilities Engineering Support Agency, Fort Belvoir, Va. 22060

71. J. G. Prather, Energy Research and Development Administration, 20 Massachusetts Ave, Washington, D. C. 20545

72. Col. W. F. Reilly, Chief, Engineering Division, U.S. Army Engineer Power Group, Ft. Belvoir, Virginia 22060 
73. J. L. Renzetti, Naval Nuclear Power Unit, 13101 Pelfrey Lane, Fairfax, Va. 22030

74. R. A. Shade, Boise Cascade Corp., One Jefferson Square, Boise, Idaho 83728

75. W. R. Smith, Power Generation Group, Babcock and Wilcox, P.0. Box 1260, Lynchburg, Virginia 24505

76-79. W. G. Sullivan, Dept. of Industrial Engineering, University of Tennessee, Knoxville, Tenn. 37916

80. R. L. Thompson, Federal Energy Administration, 1200 Pennsylvania Ave., Washington, D. C. 20461

81. Leonard Topper, Energy Research and Development Administration, 20 Massachusetts Ave., Washington, D. C. 20545

82. Seth Tuttle, Program Manager (SIA), National Science Foundation, 1800 G Street, Washington, D. C.

83. A. M. Weinberg, Oak Ridge Associated Universities, P.O. Box 117 , Oak Ridge, Tenn. 37830

84. R. W. Wendes, Amoco Oil Co., M.C. 1105, Box 61102, Chicago, Ill. 60680

85. T. W. West, Dept. of Industrial Engineering, University of Tennessee, Knoxville, Tenn. 37916

86. J. Crowley, United Engineers and Constructors, Inc., 1401 Arch Street, Philadelphia, Pa. 19105

87. Director, Div. of Nuclear Research and Applications, Energy Research and Development Administration, Washington, D.C. 20545

88-97. T. Beresovski, Div. of Nuclear Research and Applications, Energy Research and Development Administration, Washington, D.C. 20545

98. K. O. Laughon, Div. of Nuclear Research and Applications, Energy Research and Development Administration, Washington, D.C. 20545

99. Director, Reactor Division, ERDA-ORO

100. Research and Technical Support Division, ERDA-ORO

101-127. Technical Information Center, ERDA-ORO 